\title{
51. INITIAL TRANSGRESSIVE PHASE OF LEG 144 GUYOTS: EVIDENCE OF EXTREME SULFATE REDUCTION ${ }^{1}$
}

\author{
Bjørn Buchardt ${ }^{2}$ and Mary Anne Holmes ${ }^{3}$
}

\begin{abstract}
The initial transgressive phase at the Leg 144 Guyots is characterized by a typical association of sedimentary facies (from bottom to top): in situ weathered volcanic rocks; variegated clays, partly pyritic; gray clay, pyritic, homogeneous, or mottled; black clay, peaty, laminated, or bioturbated; and marine argillaceous limestone. Site 877 at Wodejebato Guyot represents the typical development of the initial transgressive phase. The black clay is rich in organic carbon (up to $40 \%$ ) and sulfur (up to $25 \%$ ). The organic matter is dominantly of terrestrial origin, but it has a significant marine, algal input. The variegated clays consist of a red, lower, sulfur-free part and a blue to gray-blue, sulfur-containing upper part. Organic carbon is not observed in this facies. The sulfur occurs as pyrite and organically bound sulfur. The isotope composition of pyrite varies from $-50 \%$ to $0 \%$, which clearly points to bacterial sulfate reduction as the origin for the high sulfur content. Pyrite formation was limited by availability of reactive iron. Because of the origin of the clays as lateritic weathering products, the amount of reactive iron was high, and pyritization proceeded to high values. The following model is suggested for sulfur enrichment in the sediments at the initial transgressive phase: (1) marine flooding of an organic-rich back-reef mangroval swamp; (2) intense bacterial reduction of marine sulfate within the black clay; and (3) downward diffusion of $\mathrm{H}_{2} \mathrm{~S}$ into the underlying clays, reduction of red iron oxides to blue-gray iron sulfides, and growth of pyrite.
\end{abstract}

\section{INTRODUCTION}

In Hans Christian Andersen's fairy tale "The Ugly Duckling" (Andersen, 1903), the beautiful white swan has to pass an initial phase of dark-gray ugliness before it reaches its mature state of dignity. Surprisingly, a similar development seems to be the rule for the western Pacific guyots drilled during the Ocean Drilling Program (ODP) Leg 144. In four out of five drilled guyots, the transition from volcanic island to carbonate platform was characterized by a special facies association including sulfitic, gray to black clays deposited under reducing conditions (Premoli Silva, Haggerty, Rack, et al., 1993). The clay was overlain by white, almost pure calcareous rocks of clear marine affinity, and the clay-covered soil profiles developed under terrestrial conditions. Thus, the clay marked the initial marine transgression (ITP) at the site.

During Leg 144, the black clay intervals and their adjacent lithologies were analyzed for sulfur and organic carbon contents. The black clay was characterized by enrichment of sulfur and organic carbon (highest values were 25 and $37 \mathrm{wt} \%$, respectively), with pyrite being the most important sulfur mineral. It soon became clear that sulfur enrichment also extended into organic-poor rocks above and below the black clay (Premoli Silva, Haggerty, Rack, et al., 1993). The downward limit of sulfur enrichment was marked by a conspicuous color change from blue-gray clays above to brick-red clays below. This boundary was interpreted as a reduction front.

Although the shipboard scientists unanimously agreed that the black clay represented the initial marine transgression of the guyot, two contrasting opinions evolved as to the origin of the sulfur enrichment: sulfate reduction in restricted marine environments as opposed to hydrothermal activity. Therefore, we decided to conduct a shore-based study of the sulfur-enriched intervals to elucidate the origin of the sulfur and to gain more insight into the character of the initial trans-

\footnotetext{
${ }^{1}$ Haggerty, J.A., Premoli Silva, L, Rack, F., and McNutt, M.K. (Eds.), 1995. Proc, ODP, Sci. Results, 144: College Station, TX (Ocean Drilling Program).

${ }^{2}$ Laboratory for Stable Isotopes, Department of Geology, University of Copenhagen, Øster Voldgade 10, DK-1350, Copenhagen K, Denmark.

${ }^{3}$ Department of Geology, University of Nebraska, Lincoln, NE 68588-0340, U.S.A.
}

gressive episodes. The study included mineralogical, geochemical, and isotope geochemical investigations of the sulfur-enriched intervals and their adjacent rocks as well as visual and optical observations.

\section{PREVIOUS STUDIES}

The transition from volcanic island phase to carbonate platform phase in guyots and at atolls has only been recorded in a few cases. A series of deep holes drilled on the Pikini and Eniwetak Atolls in the Marshall Islands reached the volcanic basement of the islands without meeting any ITP-like features (Emery et al., 1954; Schlanger, 1963). ODP Leg 143 (Sager, Winterer, Firth, et al., 1993) encountered organic carbon-enriched clayey wackestone and packstone with intervals of pyritic clay and organic matter in the deepest part of the platform at Allison Guyot (Site 865) in the Mid-Pacific Mountains. Its depositional environment was interpreted as shallow, restricted, marshy water near land. On the same leg, Site 866 at Resolution Guyot in the western Mid-Pacific Mountains (Sager, Winterer, Firth, et al., 1993) penetrated the calcareous platform and subaerially weathered basalt below. The contact between limestone and basalt was sharp with gray, pyrite-containing oolitic grainstone resting directly on the basalt surface.

Hein et al. (1988) reported black muds at the transition between lagoonal and volcanic rocks in a study of shallow boreholes in the Aitutaki Atoll, Cook Islands, South Pacific. Carbonate sand and limestone were found to overlie kaolinitic and goethitic muds formed by weathering of an underlying basalt flow of probable Pleistocene age. The uppermost meter of the mud was enriched in organic matter and pyritic sulfur and interpreted as a swamp deposit formed in a stagnant pond that was periodically replenished by seawater.

\section{MATERIALS AND METHODS \\ Shipboard Analytical Program}

During Leg 144, seven sites (Sites 871-877) were drilled at LoEn, Limalok, and Wodejebato guyots in the Marshall Islands, one site (Site 878) at MIT Guyot, and two sites (Sites 879 and 880) at TakuyoDaisan (Seiko) Guyot, all in the western Pacific Ocean (see site map preceding the title page). For detailed descriptions of sites, see Premoli Silva, Haggerty, Rack, et al. (1993). 
All samples were collected during the leg from fresh, split cores according to standard procedures (see "Explanatory Notes" in Premoli Silva, Haggerty, Rack, et al., 1993). Usually, turnover time from drilling to sampling was less than $24 \mathrm{hr}$. However, sampling from Sites 871 and 874 was delayed considerably, and desiccation and oxidation were seen to affect some samples. Sulfitic samples were not expected during the leg, and facilities for handling such materials (nitrogen glove box, etc.) were not on board. Consequently, all sulfitic samples were freeze-dried and stored in air-tight vials following the same procedure used for other geochemical samples.

Because the ITP sequence was thin in all cores, material available for geochemical investigations was limited to less than $5 \mathrm{~g}$ per sample. It was therefore necessary to define an analytical program dividing samples between different analytical objectives. The shipboard analytical procedure included determination of calcium carbonate content by coulometry and of total organic carbon (TOC), total sulfur $(\mathrm{S})$, and total nitrogen $(\mathrm{N})$ contents by elemental analysis on all collected samples. The procedures are described in the "Explanatory Notes" chapter in Premoli Silva, Haggerty, Rack, et al. (1993). Total organic carbon (TOC) content was calculated from the difference between total carbon and carbonate carbon. All amounts were calculated as weight percent (wt\%). Detection limits for organic carbon and sulfur were $0.4 \%$. Reproducibility expressed as standard deviation for ten consecutive runs was $1.5 \%$ for carbonate determination and $2 \%$ for organic carbon and sulfur determinations.

\section{Shore-based Analytical Program}

Shore-based analytical work included mineralogical characterization by X-ray diffraction (XRD), carbonate determination by titration, sulfur and carbon determinations, organic matter characterization, stable isotope $(\mathrm{C}, \mathrm{O}$, and $\mathrm{S})$ analyses; $\mathrm{Fe}$-analyses by inductively coupled plasma mass spectrometry (ICP/MS) and atomic absorption spectrophotometry (AAS); and visual inspection by light microscope and scanning electron microscope (SEM). Highest priority was given to stable isotope analyses, whereas mineralogical and organic geochemical investigations were limited to a few, representative samples. The XRD analyses were performed on an Enraf Nonius Delft Diffractis instrument (Copenhagen) and a Scintag PAD V instrument (Lincoln) using CuK $\alpha$ radiation at $40 \mathrm{kV}$ and $35 \mathrm{~mA}$. Samples were powdered and treated according to the description in Holmes (this volume). Results are reported semiquantitatively.

\section{Carbon and Sulfur Content}

Carbonate content was determined using precision titration with $\mathrm{NaOH}$ following dissolution of the samples in $0.05 \mathrm{~N} \mathrm{HCl}$ and boiling for $20 \mathrm{~min}$. Analytical grade $\mathrm{CaCO}_{3}$ was used as standard. Precision was better than $0.5 \%$. Total carbon and sulfur contents were measured in an Eltra Metalyt $90 \mathrm{~S}$ instrument by infrared absorption of carbon and sulfur dioxide after combustion of $200 \mathrm{mg}$ samples at $1250^{\circ} \mathrm{C}$ in an oxygen atmosphere. Detection limit for the Metalyt is $0.02 \%$ for both carbon and sulfur, precision is $\pm 1 \%$ of sample content. Total organic carbon content was calculated from total carbon and carbonate carbon results.

\section{Stable Isotopes}

Carbon isotope composition of organic matter and carbon and oxygen isotope composition of calcareous matter were determined according to standard procedures. Samples containing more than $0.5 \% \mathrm{TOC}$ were treated with hot $\mathrm{HCl}$ to remove carbonates, extracted in dichloromethane to remove soluble organic compounds, and combusted at $900^{\circ} \mathrm{C}$ in a flow of oxygen and helium (Buchardt et al., 1986). The resulting $\mathrm{CO}_{2}$ was cryogenically purified, collected in pyrex break-seals having a 6 -mm outer diameter, and measured for ${ }^{13} \mathrm{C} /{ }^{12} \mathrm{C}$ ratios in a Finnigan MAT 250 mass spectrometer. Carbonate- containing samples were dissolved in vacuo in $98 \%$ phosphoric acid at $50^{\circ} \mathrm{C}$, and the evolved $\mathrm{CO}_{2}$ was cryogenically purified, collected in 6-mm-o.d. pyrex break-seals, and measured for ${ }^{18} \mathrm{O} /{ }^{16} \mathrm{O}$ and ${ }^{13} \mathrm{C} /{ }^{12} \mathrm{C}$ ratios in a Finnigan MAT 250 mass spectrometer. Isotopic ratios are reported as $\delta^{34}$ values relative to the PDB standard (Craig, 1957). Reproducibility, expressed as standard deviation for ten preparations of the same sample, is better than $0.05 \%$ for oxygen and $0.03 \%$ for carbon. Sulfur isotope analyses were performed on the pyrite/marcasite fraction of the sedimentary sulfur at the Geological Institute, Ruhr-Universität Bochum, Germany. This fraction amounts to more than $95 \%$ of the total sulfur in most samples; the remaining sulfur is dominated by sulfate formed by oxidation of pyrite during shipboard sample handling or by organic sulfur. Samples for sulfur isotope analyses were prepared according to the procedure of Canfield et al. (1986), which involves reduction of disulfides by $\mathrm{CrCl}_{2}$ to $\mathrm{H}_{2} \mathrm{~S}$, precipitation of $\mathrm{H}_{2} \mathrm{~S}$ as $\mathrm{ZnS}$, conversion of $\mathrm{ZnS}$ to $\mathrm{Ag}_{2} \mathrm{~S}$ with $\mathrm{AgNO}_{3}$ solution, and combustion of $\mathrm{Ag}_{2} \mathrm{~S}$ to $\mathrm{SO}_{2}$ with $\mathrm{V}_{2} \mathrm{O}_{5} \cdot{ }^{34} \mathrm{~S} /{ }^{32} \mathrm{~S}$ ratios of the evolved $\mathrm{SO}_{2}$ were determined on a Finnigan MAT 251 mass spectrometer. Reproducibility was better than $\pm 0.3 \%$. Results are reported as $\delta^{34}$ values relative to the CDT standard.

\section{Organic Matter Screening}

Organic matter screening was carried out on a Delsi Rock Eval instrument at the Danish Geological Survey according to standard procedures (Espitalié et al., 1977). Only samples with more than $1 \%$ TOC were considered suitable for analysis. Selected samples were exposed to organic matter extraction by standard Soxtech technique employing a dicholomethane-methanol mixture. Extract composition was determined by high pressure liquid chromatography (HPLC). Saturated fractions were characterized by standard gas chromatographic techniques on an HP5890 Series II gas chromatograph. Amount of organically bound sulfur was determined by the Geoelf Sulphur Analyser (GSA) instrument at Geolab Nor in Trondheim, Norway. The instrument employs a sulfur selective chemiluminescence detector (SCD) and a pyrolysis unit. Only organic sulfur amounting to more than $5 \%$ of total sulfur can be measured by this method.

\section{Iron Determinations}

Determination of $\mathrm{HCl}$ volatile iron was done on selected samples by hot $6 \mathrm{~N} \mathrm{HCl}$ leaching for $2 \mathrm{hr}$ followed by atomic absorption spectrofotometry. This method is poorly calibrated with regard to iron silicates (Raiswell et al., 1994). Because the amount of such silicates in the ITP sediments is negligible (see paragraph on mineralogy), however, the error was not considered to influence our conclusions. Total iron concentrations were measured by ICP/MS after dissolution in $\mathrm{HF}$ and $\mathrm{HNO}_{3}$ or by $\mathrm{AAS}$ after leaching by $6 \mathrm{~N} \mathrm{HCl}$ and dissolution in aqua regia. Scanning electron microscopy was performed on a Philips SEM 515 instrument using gold-coated, fractured, or powdered samples.

\section{CORE DESCRIPTIONS}

The location of the guyots described in the text is shown on the site map preceding the title page. The lithological divisions given refer to those of Premoli Silva, Haggerty, Rack, et al. (1993), where detailed descriptions of the individual units can also be found. A general compilation of the ITP sequences is given in Figure 1.

\section{Limalok Guyot}

Site 871 was located centrally on the Limalok Guyot and included three holes (Holes 871A, 871B, and 871C). In Hole 871C, the seafloor was reached at 1234.6 meters below sea level (mbsl), and total drilling amounted to 500.0 meters below seafloor (mbsf). The ITP sequence was encountered only in Hole 871C. Holes 871A and 871B 


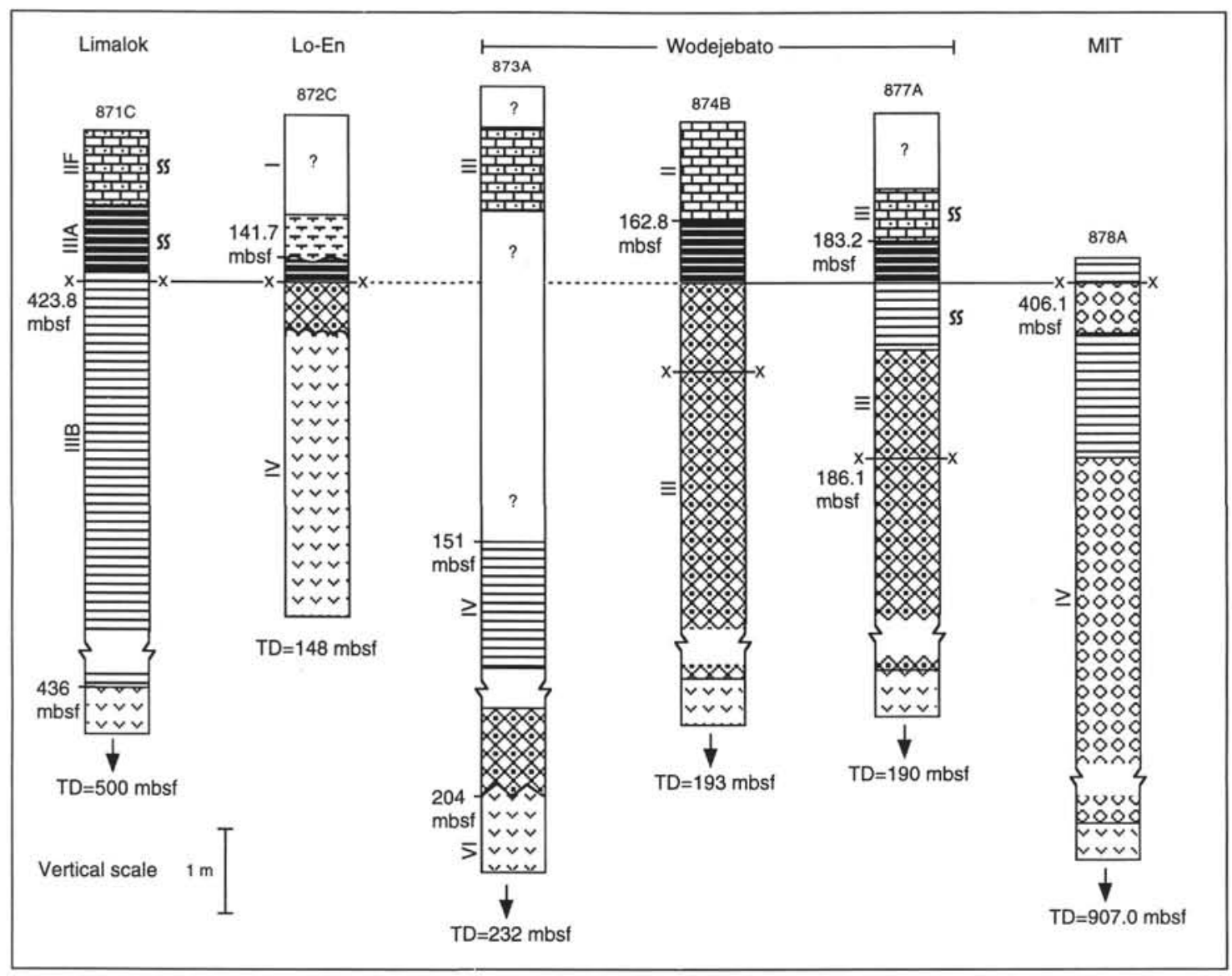

Legend

Figure 1. Comparison of lithological sections of the ITP sequence in Holes 871C, 872C, 873A, 874B, 877 A, and 878A. Important depths are given in meters below seafloor (mbsf). Roman numerals refer to lithologic units as defined in Premoli Silva, Haggerty, Rack, et al. (1993).

were terminated in pelagic ooze of Pleistocene to early Miocene age. Hole $871 \mathrm{C}$ penetrated $289 \mathrm{~m}$ of middle Eocene to late Paleocene platform carbonates, $29 \mathrm{~m}$ of late Paleocene to older terrestrial clays and volcaniclastic deposits, and $48 \mathrm{~m}$ of undated basalt (Premoli Silva, Haggerty, Rack, et al., 1993).

The ITP sequence includes (from top to bottom) $0.6 \mathrm{~m}$ of dark gray, argillaceous, skeletal limestone of early late Paleocene age (lithologic Subunit IIF); $0.9 \mathrm{~m}$ of bioturbated, black, organic-rich clay (upper part of lithologic Subunit IIIA); and $12.1 \mathrm{~m}$ of mottled, variegated clays (lower part of lithologic Subunit IIIA and lithologic Subunit IIIB). The sequence is covered by middle Eocene to late Paleocene calcareous deposits of platform facies and underlain by $15.6 \mathrm{~m}$ of volcaniclastic deposits and $58 \mathrm{~m}$ of dark-gray basalt.

A sharp increase in aluminum and iron concentrations seen in the geochemical log at $418 \mathrm{mbsf}$ defines the top of the skeletal lime- stone (Premoli Silva, Haggerty, Rack, et al., 1993). Downward, the lower boundary of the mottled clay is placed at 435.9 mbsf. Thus, the cumulative thickness of the ITP sequence at Site 871 is approximately $18 \mathrm{~m}$. A minor sample of organic-rich black clay collected from the core catcher (Sample 144-871C-31R-CC, 44-49 cm) may indicate repeated occurrences of the black clay within the platform limestone above.

The skeletal limestone of lithologic Subunit IIF is poorly sorted, coarse grained at the bottom and finer grained toward the top. It contains a highly diverse fauna including red and green algae, large benthic foraminifers, fragments of thick-shelled molluscs, echinoderm fragments and corals (Premoli Silva, Haggerty, Rack, et al., 1993, p. 53). Pyrite is common as framboids and shell replacements. The preservation of aragonite in the mollusc shells is remarkable and indicates special diagenetic conditions in the subunit. 
The black clay at the top of lithologic Subunit IIIA is characterized by high concentrations of pyritic sulfur and organic carbon (up to 12 and $10 \mathrm{wt} \%$, respectively). Patches in the clay filled with marine skeletal grains have been interpreted as burrows (Premoli Silva, Haggerty, Rack, et al., 1993), where the infillings represent the biota of the overlying skeletal limestone. Downward, the color of the clay gradually changes from black into light gray with yellowish, limonitic patches. The boundary between lithologic Subunits IIIA and IIIB is placed at a distinct downward color change in the mottled clay from gray to brick-red at a depth of $423.8 \mathrm{mbsf}$. This boundary coincides with the boundary between organic carbon-free, but pyritic sulfurcontaining, clays above, and carbon- and sulfur-free clays below.

The mottled and variegated clays below the black clay represent a soil profile in deeply weathered basalt (Holmes, this volume). Only the C-horizon is preserved in the soil. The lack of A- and B-horizons in the soil profile is attributed to erosional removal of at least $10 \mathrm{~m}$ of soil before deposition of the black clay. The soil developed in an upland area under tropical conditions and moderate rainfall.

\section{Lo-En Guyot}

Site 872 is located on the central portion of Lo-En Guyot in the Marshall Islands. Water depth at the site was $1094 \mathrm{~m}$, and maximal penetration was 192.5 mbsf (Premoli Silva, Haggerty, Rack, et al., 1993). Three holes were drilled at the site, all penetrating the pelagic cap. The holes terminated in basaltic rocks without encountering any platform limestone. In Holes $872 \mathrm{~A}$ and $872 \mathrm{~B}$, foraminifer ooze of late Oligocene age rested on a thin conglomerate made up of basaltic pebbles and limestone matrix containing late Santonian to late Paleocene microfossils. In Hole 872C, upper Oligocene foraminifer ooze overlies altered, vesicular basalt and undated, gray-green to brown, mottled clay (interval 144-872C-17X-CC, 20-50 cm). Boundaries between ooze, clay, and basalt were not encountered and cannot be inferred from the log data.

\section{Wodejebato Guyot}

Wodejebato Guyot (formerly Sylvania Guyot) in the Ralik Chain of the Marshall Islands constituted one of the major targets of Leg 144. Five sites (Sites 873-877) were drilled on the guyot (Premoli Silva, Haggerty, Rack, et al., 1993), with water depths ranging from $1335 \mathrm{~m}$ (Site 873) to $1420 \mathrm{~m}$ (Site 876). Maximal penetration was 232 mbsf (Site 873).

\section{Site 873}

Site 873 is located on the southern central summit of Wodejebato. Two holes were drilled at the site. The penetrated section included 54 $\mathrm{m}$ of Pleistocene to early Miocene pelagic cap (lithologic Unit I, Premoli Silva, Haggerty, Rack, et al., 1993); 5 m of phosphatized limestone conglomerate of Eocene age (lithologic Unit II); $81 \mathrm{~m}$ of platform carbonates of Maastrichtian to Campanian age (lithologic Unit III); $24 \mathrm{~m}$ of noncalcareous, ferrugineous clay and claystone of indeterminate age (lithologic Unit IV); and $57 \mathrm{~m}$ of altered basalt and volcanic breccia of early Campanian age (Pringle, this volume).

The only ITP-type deposits recovered from this site were red, ferrugineous clay at the upper part of lithologic Unit IV in Hole 873A, which represented the B-horizon of a well-developed tropical soil (Holmes, this volume). No A-horizon was observed. Downhole logging indicates that the upper $4.1 \mathrm{~m}$ of the section was not recovered, but the low concentrations of sulfur and uranium in this interval do not point to any occurrence of reduced clays.

However, the observation of natroalunite $\left(\mathrm{NaAl}_{3}\left(\mathrm{SO}_{4}\right)(\mathrm{OH})_{6}\right)$ as thin veins and blebs in the upper, massive red clay of lithologic Unit IV (Holmes, this volume) suggests that reducing conditions may well have existed before the formation of the carbonate platform. Natroalunite is known to form by reactions between kaolinite and sulfuric- acid-rich solutions in soil horizons below transgressive, pyritic clays (Chitale and Güven, 1987).

\section{Site 874}

Site 874 is located on the inner perimeter ridge of the northeast side of Wodejebato. Two holes were drilled at the site, but only Hole 874B penetrated into deeper parts of the guyot (Premoli Silva, Haggerty, Rack, et al., 1993). Depth to the seafloor at Hole 874B was $1374.9 \mathrm{~m}$, and a total thickness of $193.5 \mathrm{mbsf}$ was penetrated.

The type of rocks encountered at the site included (from top to bottom) $0.1 \mathrm{~m}$ of manganese encrusted limestone of late middle Eocene age (lithologic Unit I; Premoli Silva, Haggerty, Rack, et al., 1993), $162 \mathrm{~m}$ of platform limestone of Maastrichtian to possible Campanian age (lithologic Unit II), $15 \mathrm{~m}$ of ferruginous black to red clay and claystone grading downward into highly altered basalt (lithologic Unit III), and $16 \mathrm{~m}$ of altered basalt (lithologic Unit IV).

The clay and claystone of lithologic Unit III include the ITP sequence of Site 874 . The unit has been subdivided into three informal subunits: (1) black clay with a thin shell bed at the bottom (interval 144-874B-21R-1, 0-44 cm); (2) bluish-gray clay with relict structures of weathered basalt (interval 144-874B-21R-1, 44-125 $\mathrm{cm}$ ), and (3) red clay with relict structures of weathered basalt (interval $144-874 \mathrm{~B}-21 \mathrm{R}-1,125 \mathrm{~cm}$, to $-22 \mathrm{R}-4,72 \mathrm{~cm}$ ).

The boundary between the black clay and the overlying platform carbonate was not recovered during drilling. The foraminifer grainstone observed at the top of Core 21R (Sample 144-874B-21R-1, 0-2 $\mathrm{cm}$ ) is a loose pebble grainstone resembling the foraminifer grainstone recovered from Core 20R (interval 144-874B-20R-1, 1-21 cm) and does not represent the boundary between lithologic Units II and III, as stated in Premoli Silva, Haggerty, Rack, et al. (1993, p. 220). However, a sharp downhole decrease in calcium content and a corresponding sharp downhole increase in iron and silica in the geochemical logs between 162 and 163 mbsf and a sharp downhole drop in resistivity observed on the Formation MicroScanner logs at 162.6 mbsf define the boundary with great precision (Premoli Silva, Haggerty, Rack, et al., 1993, p. 243). The boundary between the red and gray clays at $164.4 \mathrm{mbsf}$ (Sample 144-874B-21R-1, $125 \mathrm{~cm}$ ) was defined from color alone.

The black clay is homogeneous and contains organic remains, mainly woody and cuticular fragments. Spores from ferns and fungi have also been reported (Premoli Silva, Haggerty, Rack, et al., 1993, p. 228). No visible pyrite was observed in the clay. The boundary to the underlying gray clay is marked by a $0.4-\mathrm{cm}$-thick "lag" deposit of highly mixed larger foraminifers and macrofossil shell fragments. Rare, well-preserved calcareous nannofossils in the lag suggest a Campanian age (Premoli Silva, Haggerty, Rack, et al., 1993, p. 227). No bioturbation was observed at this level or in the overlying black clay.

The gray clay had low to very low concentrations of organic matter, whereas sulfur concentrations remained high in the upper part and dropped to low in the lower part of the clay. Euhedral crystals of submillimeter-sized pyrite were abundant in the clay (PI. 1). The red clay resembles the overlying gray clay except in color and lack of sulfur. No organic matter was observed in this subunit. The marked color change from gray to red has been interpreted as a redox boundary (Holmes, this volume). Except for the upper black clay, the whole lithologic Unit III represents an erosional truncation of a tropical soil profile, for which only the base of the $\mathrm{C}$-horizon has been preserved (Holmes, this volume). An estimated total thickness of the soil profile of $20-30 \mathrm{~m}$ leaves at least $5-10 \mathrm{~m}$ of the profile to have been lost by erosion before the deposition of the black clay.

\section{Sites 875 and 876}

Sites 875 and 876 are located on the northeastern rim of the Wodejebato Guyot. They are situated $1.67 \mathrm{~km}$ apart, on the discontinuous outer perimeter ridge (Premoli Silva, Haggerty, Rack, et al., 
1993). Three holes were drilled at Site 875 (Holes 875A, 875B, and $875 \mathrm{C}$ ), one hole at Site 876 (Hole 876A). In general, the lithologies penetrated at the two sites were identical. No pelagic cap was found except for thin Mn-encrusted planktonic foraminifer limestone of late Paleocene to late middle Eocene age (lithologic Unit I). The Mn-encrusted limestone was underlain by $125-145 \mathrm{~m}$ of skeletal grainstone and packstone of Maastrichtian age (lithologic Unit II). The holes were terminated after penetration of less than $10 \mathrm{~m}$ of basalt (lithologic Unit III) of early Campanian age (Pringle, this volume).

No deposits of the ITP type were represented at these sites. The observation of fresh, secondary pyrite in the uppermost pieces of the basalt at Site 875 (interval 144-875C-14M-1, 68-76 cm) does, however, suggest the development of reducing conditions at the initial marine transgression at the site (Premoli Silva, Haggerty, Rack, et al., 1993, p. 278). The basalt in Hole $875 \mathrm{C}$ reflects a significant degree of alteration, probably by subaerial weathering, but any soil profile has been removed before deposition of the overlying skeletal grainstone. In contrast, basalts at Site 876 have only undergone a relatively brief period of oxidative weathering.

\section{Site 877}

Site 877 is located on the inner perimeter ridge of northeastern Wodejebato Guyot, $0.7 \mathrm{~km}$ northeast of Site 874 and $1.2 \mathrm{~km}$ westsouthwest of Site 876 . Only one hole (Hole 877A) was drilled at the site. The hole penetrated a thin, manganese crust (lithologic Unit I) containing early and middle Eocene fossils before encountering about $183 \mathrm{~m}$ of platform and reef carbonates (lithologic Unit II) of late Campanian to Maastrichtian age; $7.3 \mathrm{~m}$ of organic-rich clay, argillaceous limestone, peat, clay, claystone, and claystone breccia of late Campanian to older age (lithologic Unit III); and terminated in volcanic breccia (Premoli Silva, Haggerty, Rack, et al., 1993).

The ITP sequence includes the uppermost $4 \mathrm{~m}$ of lithologic Unit III as found in Core 144-877A-20R. The top of the sequence is arbitrarily placed below a pale brown foraminifer grainstone clast (Sample 144877A-20R-1, 0-7 cm), which, however, may be caved from above. Because the recovery of Core $144-877 \mathrm{~A}-19 \mathrm{R}$ was very low $(3.0 \%$, Premoli Silva, Haggerty, Rack, et al., 1993) and no downhole logging was performed at this site, it is not possible to determine the upper boundary of the ITP sequence with better precision. The bottom of the ITP sequence is placed at the significant color change from gray to red claystone between Samples 144-877A-20R-3, 79-80 cm, and 144$877 \mathrm{~A}-20 \mathrm{R}-3,99-100 \mathrm{~cm}$, at a depth of $186.10 \mathrm{mbsf}$. The ITP sequence at Site 877 has the most complete development of the investigated sites. The sequence included the following lithotypes (from top to bottom): fine to medium grained, bioturbated argillaceous grainstone with sand-sized shell fragments; laminated, black, peaty clay, rich in plant remains; light gray, mottled or bioturbated clay with questionable remains of plant roots; and blue-green to red clay and claystone with relict structures of weathered volcaniclastic breccia. Pyrite was observed as euhedral crystals in the upper part of the mottled clay.

At the top of the sequence, the argillaceous grainstone and the black clay were seen to alternate (interval 144-877A-20R-1, 10-77 $\mathrm{cm})$. At least three upward-coarsening cycles can be observed in this interval. The grainstone contains marine nannofossils of late Campanian age with an element of reworked Cenomanian taxa (Premoli Silva, Haggerty, Rack, et al., 1993, p. 294). The black clay is dominated by woody tissues. Fungal and fern spores, foraminiferal linings and acritarchs have also been reported (Premoli Silva, Haggerty, Rack, et al., 1993, p. 299). The section below the black clay has been interpreted as the base of a soil profile, where the A- and B-horizons are missing (Holmes, this volume).

\section{MIT Guyot}

Site 878 is located at the northeastern end of the MIT Guyot at $27^{\circ} 19.143^{\prime} \mathrm{N}, 151^{\circ} 53.028^{\prime} \mathrm{E}$, at a water depth of $1323 \mathrm{~m}$. Hole $878 \mathrm{~A}$ penetrated $3 \mathrm{~m}$ of pelagic ooze (lithologic Unit I), $397 \mathrm{~m}$ of platform carbonates (lithologic Units II and III), $302 \mathrm{~m}$ of polymictic breccia (lithologic Unit IV), $118 \mathrm{~m}$ of platform carbonate (lithologic Unit V), and $287 \mathrm{~m}$ of basalt (lithologic Unit VI). Age of lithologic Units II to IV is early Aptian to late Albian (Premoli Silva, Haggerty, Rack, et al., 1993). No indications of an ITP sequence were observed at the boundary between basalt and platform carbonate. However, the uppermost meter of the polymictic breccia and an overlying greenish gray clay (Subunit IVA and top of Subunit IVB) contain abundant disseminated pyrite and may represent an incomplete ITP sequence.

\section{Takuyo-Daisan (Seiko) Guyot}

Site 879 was located at the southern ridge of Takuyo-Daisan (Seiko) Guyot and included one hole (Hole 879A). The seafloor was reached at $1500.8 \mathrm{~m}$ below sea level and total drilling amounted to 226.5 mbsf (Premoli Silva, Haggerty, Rack, et al., 1993). Hole 879A penetrated $151 \mathrm{~m}$ of platform limestone (lithologic Subunits IA to IC), $19 \mathrm{~m}$ of mixed argillaceous limestone and volcanic conglomerate (lithologic Subunits ID and IE), $20 \mathrm{~m}$ of claystone with relict volcanic texture (lithologic Unit II), and $36 \mathrm{~m}$ of basalt breccia (lithologic Unit III). The age of the sedimentary sequence is late Aptian to Albian.

At Site 879, the initial transgression was more complex than at the other guyots, and the ITP sequence is not typical. No major TOC or S enrichments were observed. A well-defined boundary between graygreen claystone with relict volcanic texture and overlying bioturbated, calcareous sand and argillaceous limestone was observed in Sample 144-879A-18R-1, $35 \mathrm{~cm}$, at $160.6 \mathrm{mbsf}$. This boundary does not coincide with the formal boundary between lithologic Units I and II as defined in Premoli Silva, Haggerty, Rack, et al. (1993), which was placed at the top of Section 144-879A-17R-2, approximately $8.7 \mathrm{~m}$ higher. Because recovery was low in Core 144-879A-17R, no information exists about most of this interval. The boundary in Section 144$879 \mathrm{~A}-18 \mathrm{R}-1$ probably reflects a marine transgression at the site. The overlying sediments of lithologic Subunits ID and IE and lithologic Unit II represent at least three shallowing-up cycles of mixed volcaniclastics, clay, and limestone, all strongly bioturbated. Sulfur enrichments between $1 \%$ and $4 \%$ were measured in the more argillaceous intervals. The clay and claystone below have been interpreted as a result of subaerial weathering of volcanic deposits (Holmes, this volume). Pyrite was reported from clays in Sections 144-879A-18R-1 and $-19 \mathrm{R}-1$. Below the gray-greenish claystone and volcanic breccia deposits, red to brown claystone was encountered in Core 144-879A-20R.

\section{RESULTS \\ Lithofacies}

The ITP sequence is characterized by one or more of four lithofacies (Table 1, Fig. 1): argillaceous limestone (Lithofacies A), black clay (Lithofacies B), mottled clay (Lithofacies C), and clay with relict structures of basaltic rocks (Lithofacies D). In most cases, the succession of lithofacies is well defined (from bottom to top: D, C, B, A). However, Lithofacies A and B occur repeatedly on top of each other in Holes $871 \mathrm{C}, 874 \mathrm{~B}$, and $877 \mathrm{~A}$ and probably reflect rapidly changing depositional conditions. In Hole $871 \mathrm{C}$, burrowing organisms have dragged material from the argillaceous limestone of Lithofacies A down into the black clay of Lithofacies B. The sequence is superimposed on volcanic rocks altered to various degree and overlaid by shallow water platform carbonates.

\section{Mineralogy}

The results of the mineralogical investigation are given in Table 2. Three classes of minerals have been identified in the ITP sequence and the underlying soil profiles: clay minerals originating from weathering and soil-forming processes of the basaltic rocks below, carbonates of skeletal origin mainly derived from the calcareous platform and lagoonal environments above, and authigenic minerals 
Table 1. Lithofacies of the ITP sequence.

\begin{tabular}{|c|c|c|c|c|c|c|c|}
\hline Lithofacies and description & $\begin{array}{l}\text { Site } \\
871\end{array}$ & $\begin{array}{l}\text { Site } \\
872\end{array}$ & $\begin{array}{l}\text { Site } \\
873\end{array}$ & $\begin{array}{l}\text { Site } \\
874\end{array}$ & $\begin{array}{l}\text { Site } \\
877\end{array}$ & $\begin{array}{l}\text { Site } \\
878\end{array}$ & $\begin{array}{l}\text { Site } \\
879\end{array}$ \\
\hline $\begin{array}{l}\text { Lithofacies A: argillaceous grainstone or packstone heavily bioturbated with shell } \\
\text { fragments in sand fraction }\end{array}$ & $\mathrm{x}$ & & & $\mathrm{x}$ & $\mathrm{X}$ & & $\mathrm{X}$ \\
\hline $\begin{array}{l}\text { Lithofacies B: clay, black, peaty laminated or partly bioturbated with varying } \\
\text { amounts of plant remains }\end{array}$ & $\mathrm{X}$ & & & $\mathrm{x}$ & $x$ & & \\
\hline $\begin{array}{l}\text { Lithofacies C: clay, gray, red or variegated homogeneous to mottled with or without } \\
\text { plant remains }\end{array}$ & $\mathrm{x}$ & $\mathrm{X}$ & & & $\mathrm{X}$ & & $\mathrm{X}$ \\
\hline $\begin{array}{l}\text { Lithofacies D: clay to claystone, gray, blue-green to red or variegated with relict } \\
\text { structures of weathered basalt or volcaniclastics }\end{array}$ & $\mathrm{x}$ & & $\mathrm{x}$ & $\mathrm{x}$ & $\mathrm{x}$ & $\mathrm{X}$ & $\mathrm{X}$ \\
\hline
\end{tabular}

formed within the ITP. The clay phase at all sites is dominated by kaolinite with minor amounts of smectite and gibbsite lower in the profiles. Frequently, the mottled clay below the sulfidic, black clay also contains minor amounts of goethite and hematite. Traces of anatase have been described from most samples (Holmes, this volume). No significant difference was observed between the clay composition of the black clay and the underlying mottled, gray and red clay.

Carbonate minerals found in the bioturbated segments of the black clay and in the skeletal packstone and grainstone above the clay included calcite, aragonite and minor amounts of Mg-calcite. Aragonite was the dominant carbonate mineral in the dark, skeletal packstone at $422 \mathrm{mbsf}$ in Hole $871 \mathrm{C}$ and its bioturbated protrusions into the underlying black clay, and was also represented in the argillaceous grainstone at $183 \mathrm{mbsf}$ in Hole $877 \mathrm{~A}$. The aragonite was found in shell fragments of mainly gastropod and pelecypod origin. Preservation of aragonite suggests a diagenetic environment distinctly different from that of the overlying calcareous units, where all aragonite was recrystallized or dissolved early in the diagenetic history (Premoli Silva, Haggerty, Rack, et al., 1993; Enos et al., this volume).

Authigenic minerals in the ITP sequence are sulfides and sulfates. In the black and gray clays, pyrite is the dominant sulfur-bearing mineral. Small amounts of marcasite have also been observed. The pyrite forms well preserved, euhedral, submillimeter concretions in the gray clay but lacks distinct crystal shapes in the black clay above, where it is mostly in the form of anhedral encrustations (Pl. 1). No well-defined framboids were found. Sulfates in the form of natrojarosite $\left(\mathrm{NaFe}_{3}\left(\mathrm{SO}_{4}\right) 2(\mathrm{OH})_{6}\right)$ and natroalunite $\left(\mathrm{NaAl}_{3}\left(\mathrm{SO}_{4}\right)(\mathrm{OH})_{6}\right)$ have been described from the gray and red clay and claystone below the black clay. Natrojarosite is found at Sites 871 and 877 , and natroalunite at Site 873 (Holmes, this volume).

The mineralogical investigation did not reveal any minerals of typical hydrothermal origin such as zeolites and opal-CT. The clay paragenesis has been interpreted by Holmes (this volume) as the result of subaerially weathering of basalt surfaces in subtropical to tropical environments. Weathering processes probably lasted from several hundred thousand years up to (or perhaps even longer than) 3 m.y.

\section{Inorganic and Organic Geochemistry}

Results of the inorganic and organic analyses of the ITP samples are shown in Tables 3 to 8 and Figures 2 to 5. The TOC and S data were discussed by Premoli Silva, Haggerty, Rack, et al. (1993). Based on the geochemical data in Table 3 and additional iron concentration data (Table 8), the ITP sequence can be divided into five chemofacies (Table 4). One or more of these chemofacies are represented at all investigated sites except Sites 875 and 876 , and the most complete development can be observed in Holes 871C, 874B, and 877A. In Hole $871 \mathrm{C}$, bioturbation has led to mixing of chemofacies A and B. Shipboard sampling did not take this problem into account.

Organic geochemical screening data include results of Rock Eval and carbon isotope analyses (Table 5 and Fig. 3). The numbers confirm the preliminary results of the shipboard analyses: organic matter is thermally immature and predominantly low in hydrogen, corresponding to terrestrial kerogen of type III (Fig. 4). However, a few samples gave increased $\mathrm{HI}$ values suggesting more algal-rich kero- gen. A moderate $\mathrm{HI}$ increase (HI values between 200 and 300 ) is seen in the TOC-rich samples from the black clay (Lithofacies B) in Hole 877A (Fig. 3C). Much stronger hydrogen enrichment (HI values up to 1000) appears in some samples from the gray clay (Lithofacies C) in Holes 871C, 874B, and 877A. Most of these samples have TOC values below $1 \%$ and may be unreliable for the Rock Eval. However, repeated analyses confirmed the numbers, and the data may be significant.

Carbon isotope composition of organic matter is a useful parameter for further classification of organic matter of kerogen type III. $\delta^{13} \mathrm{C}$ values of the investigated samples vary from $-20 \%$ to $-28 \%$ (Fig. 3D). The TOC-rich samples from the black clays of Lithofacies $\mathrm{B}$ all have $\delta^{13} \mathrm{C}$ values between $-22 \%$ and $-25 \%$. These numbers are comparable to the carbon isotope composition of the strongly oxidized organic matter in the pelagic caps (see Israelson et al., this volume). Similar numbers have been obtained from terrestrial organic matter of Mesozoic age (Buchardt and Nielsen, 1991). The most ${ }^{13} \mathrm{C}$-enriched samples are from organic-rich intervals in the platform carbonates as seen immediately above the ITP in Holes $873 \mathrm{~A}$ and $879 \mathrm{~A}$ and are similar to modern organic matter of marine origin (Deines, 1980). In Holes 874B and 877A, the deeper part of the gray clay of Lithofacies $\mathrm{C}$ is characterized by organic matter depleted in ${ }^{13} \mathrm{C}\left(\delta^{13} \mathrm{C}_{\mathrm{OM}}\right.$ values between $-25 \%$ and $\left.-28 \%\right)$. These samples are all low in TOC $(<2 \%)$, but high in HI (see discussion above). Depleted carbon isotope compositions are characteristic for modern organic matter of terrestrial origin (Deines, 1980) but may not be indicative for a similar origin in pre-Neogene time (Dean et al., 1986). In contrast, Lewan (1986) has shown how hydrogen-rich marine, organic matter of algal origin generally is strongly ${ }^{13} \mathrm{C}$-depleted throughout most of the Phanerozoic record.

Extraction of soluble organic matter (SOM) was performed only on a limited number of samples (Table 6). In all cases, the amount of SOM was low (5\%-11\% of TOC) and had a composition dominated by polar components $(65 \%-100 \%$ of SOM). These numbers reflect the thermally immature character of the organic matter. Preliminary GC analyses of the aliphatic fraction of the SOM (not shown) suggest a heterogeneous composition of the organic matter including both algal and herbaceous components.

Organic sulfur concentrations were below the detection limit in most samples (Table 7). One sample from Hole 874B (Sample 144874B-21R-1, 112-113 cm), and three samples from Hole 877A (Samples 144-877A-20R-1, 92-94 and 101-102, and 20R-2, 98-99 cm) had $\mathrm{S}_{\text {org }} / \mathrm{S}_{\text {tot }}$ ratios from 0.06 to 0.23 . The highest ratios were found in the TOC- and S-rich black clay of Lithofacies B in Hole 877A.

Sulfur isotope composition of disseminated pyrite from Lithofacies $\mathrm{A}, \mathrm{B}$, and $\mathrm{C}$ varied from $\delta^{34} \mathrm{~S}$ values of $+1.7 \%$ to $-46.1 \%$ (Table 7 , Fig. 5). No clear relationships were seen between ${ }^{34} \mathrm{~S} /{ }^{32} \mathrm{~S}$ ratios and sulfur content or concentration of organic matter. The most sulfur-enriched samples $(>10 \% \mathrm{~S})$ had $\delta^{34} \mathrm{~S}$ values from $-12.7 \%$ to $-37.5 \%$, whereas intervals low in sulfur could be both ${ }^{34} \mathrm{~S}$ enriched (Hole $877 \mathrm{~A}$ ) or ${ }^{34} \mathrm{~S}$ depleted (Hole $874 \mathrm{~B}$ ). The pyrite in the altered polymictic breccia in Hole $878 \mathrm{~A}$ was strongly depleted in ${ }^{34} \mathrm{~S}\left(\delta^{34} \mathrm{~S}\right.$ values from $-41.7 \%$ to $-46.1 \%$ ). Only in Hole $877 \mathrm{~A}$ did the sulfur isotope composition change systematically with depth in the ITP, here from more ${ }^{34} \mathrm{~S}$-depleted to more ${ }^{34} \mathrm{~S}$-enriched values (Fig. 6). 
Table 2. Mineralogical composition of the ITP sequence.

\begin{tabular}{|c|c|c|c|c|c|c|c|c|c|c|c|c|c|}
\hline $\begin{array}{l}\text { Core, section } \\
\text { interval }(\mathrm{cm})\end{array}$ & $\begin{array}{l}\text { Depth } \\
\text { (mbsf) }\end{array}$ & Lithology & Calcite & $\begin{array}{c}\mathrm{Mg} \\
\text { calcite }\end{array}$ & Aragonite & Pyrite & Marcasite & Smectite & Kaolinite & Gibbsite & Goethite & Hematite & Other \\
\hline \multicolumn{14}{|l|}{$144-871 \mathrm{C}$} \\
\hline 31R-CC, $44-49$ & $(413.29)$ & Clay, black, calcareous & +++ & & ++ & + & & 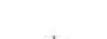 & + & $\operatorname{Tr}$ & & & \\
\hline $\begin{array}{l}32 R-1,4-42 \\
32 R-1,44-49\end{array}$ & $\begin{array}{l}422.19 \\
422.95\end{array}$ & $\begin{array}{l}\text { Iay, black, calcareous } \\
\text { Packstone, dark }\end{array}$ & $\begin{array}{c}+ \\
++\end{array}$ & + & $\begin{array}{c}+ \\
+++\end{array}$ & +++ & & + & $\begin{array}{l}+ \\
+\end{array}$ & & $\mathrm{Tr}$ & & \\
\hline $32 \mathrm{R}-1,52-53$ & 423.02 & Clay, gray, calcareous & +++ & $\begin{array}{lll}+ \\
+\end{array}$ & t+ & + & $\mathrm{Tr}$ & & + & $\mathrm{Tr}$ & & & \\
\hline $32 \mathrm{R}-1,53-54$ & 423.03 & Clay, gray & + & & ++ & t++ & & + & + & & & & \\
\hline $32 \mathrm{R}-1,58-60$ & 423.08 & Clay, gray & + & & + & n+t & & + & ++ & & & & \\
\hline \multicolumn{14}{|l|}{ 144-874B- } \\
\hline $21 \mathrm{R}-1,0-5$ & 162.82 & Clay, black & & & & t++ & & & + & & & & \\
\hline $21 R-1,25-27$ & $\begin{array}{l}102.82 \\
163.05\end{array}$ & Claystone, black & & & & $\begin{array}{l}+++ \\
++1 \\
t+1\end{array}$ & $\mathrm{Tr}$ & + & $\begin{array}{llll}+ \\
++\end{array}$ & + & & & \\
\hline $21 R-1.74-75$ & 163.54 & Claystone & $\mathrm{Tr}$ & & & ++ & $\mathrm{Tr}$ & + & + & & $\mathrm{Tr}$ & & \\
\hline $21 R-1,112-113$ & 163.92 & Clay, gray & & & & ++ & ++ & & + & & & & \\
\hline \multicolumn{14}{|l|}{ 144-877A- } \\
\hline $20 \mathrm{R}-1,42-44$ & 183.12 & Clayey limestone & ++ & + & ++ & +++ & & & + & + & $\operatorname{Tr}$ & & \\
\hline $20 \mathrm{R}-1,70-71$ & 183.40 & Clayey limestone & ++ & & h+ & ++ & & & + & + & & & \\
\hline $20 \mathrm{R}-1,81-82$ & 183.51 & Clay, black & & & & h+ & + & & + & + & & & \\
\hline $20 \mathrm{R}-1,92-94$ & 183.62 & Clay, black & & & & t+t & + & & + & & & & \\
\hline $20 \mathrm{R}-1,101-102$ & 183.71 & Clay, black & $\mathrm{Tr}$ & & & t++ & + & & + & & & & \\
\hline $20 R-2,1-2$ & 183.76 & Clay, black, peaty & $\mathrm{Tr}$ & & & +++ & + & & + & $\mathrm{Tr}$ & & & \\
\hline $20 \mathrm{R}-2,15-16$ & 183.95 & Clay, black, peaty & & & & ++ & $\mathrm{Tr}$ & $\mathrm{Tr}$ & + & + & & & \\
\hline $20 \mathrm{R}-2,34-35$ & 184.09 & Clay, black, peaty & & & & $\begin{array}{c}+++ \\
++\end{array}$ & $\mathrm{Tr}$ & & + & + & & & Natrojarosite \\
\hline $20 \mathrm{R}-2,53-55$ & 184.32 & Clay, gray & & & & ++ & + & $\mathrm{Tr}$ & + & + & + & & \\
\hline $20 R-2,61-62$ & $\begin{array}{l}184.32 \\
184.42\end{array}$ & $\begin{array}{l}\text { Clay, gray } \\
\text { Clay, gray }\end{array}$ & & & & $\stackrel{++}{+}$ & $\mathrm{Tr}^{+}$ & $\mathrm{Tr}$ & $\begin{array}{l}+ \\
+\end{array}$ & + & + & & \\
\hline 20R-2, 98-99 & 184.79 & Clay, gray & & & & ++ & + & $\mathrm{Tr}$ & + & & + & & \\
\hline 20R-3, 9-10 & 185.34 & Claystone, greenish gray & & & & +++ & + & + & + & & + & & Natrojarosite \\
\hline $20 \mathrm{R}-3,39-40$ & 185.64 & Claystone, greenish gray & & & & ++4 & & $\begin{array}{l}t_{+} \\
+\end{array}$ & + & & + & & \\
\hline $20 \mathrm{R}-3,79-80$ & 186.04 & Claystone, greenish gray & & & & + & & + & + & & + & & \\
\hline $20 \mathrm{R}-3,99-100$ & 186.25 & Claystone, red & & & & & & + & + & & + & + & \\
\hline
\end{tabular}

Notes: Mineral occurrence given semiquantitatively, with $+++=$ abundant, $++=$ frequent, $+=$ seldom, and $\mathrm{Tr}=$ trace. Clay minerals are underrepresented as a result of preparation procedures 

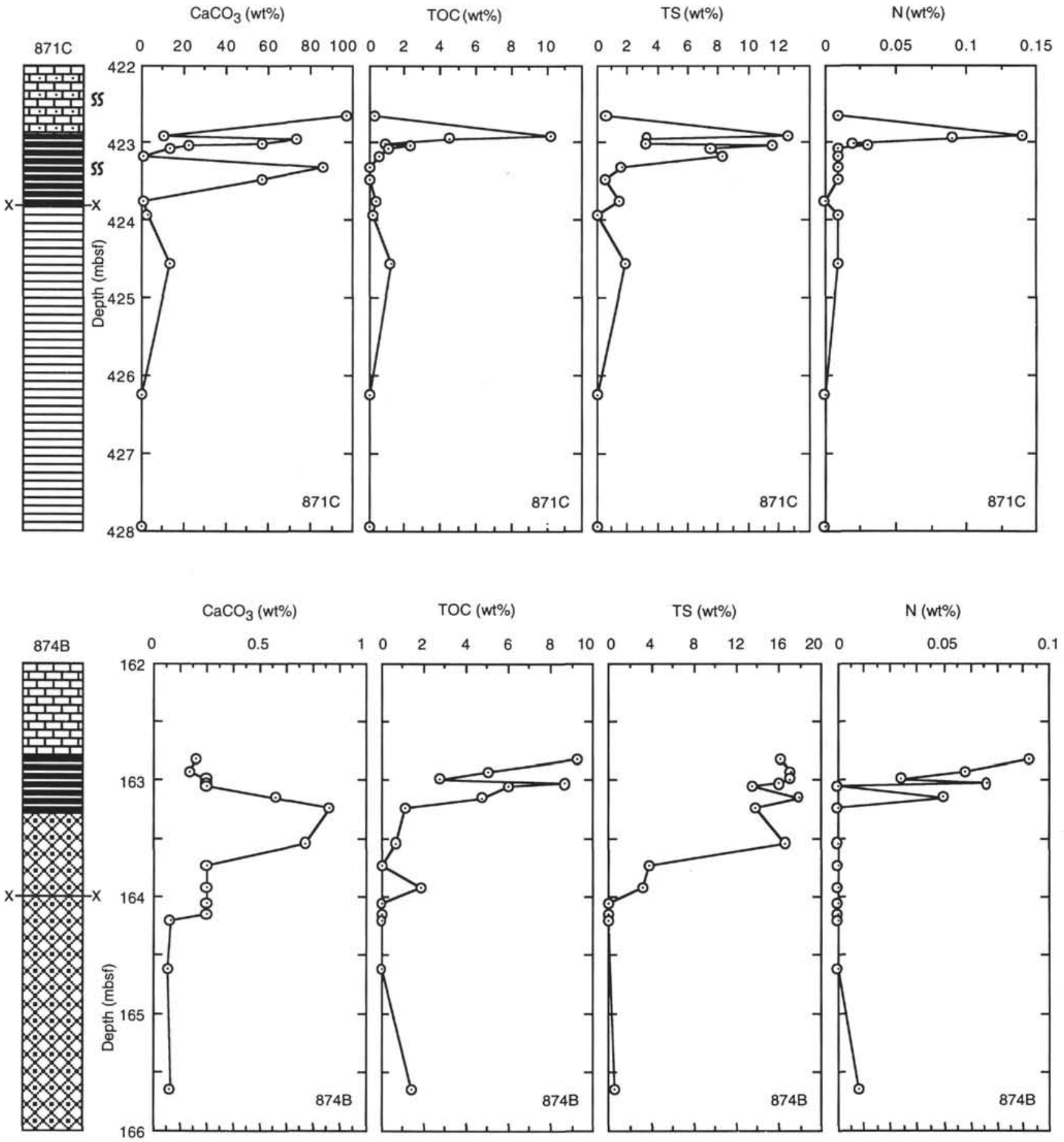

Figure 2. Results of geochemical screening of the ITP sequence in Holes 871C (Limalok Guyot), 874B and 877A (Wodejebato Guyot), and 878A (MIT Guyot). Lithologies are in accordance with the lithofacies definitions given in Table 1. All geochemical data are given in Table 3.

Fe concentrations have been determined in a limited number of samples from Sites 871,874 , and 877 , mainly for calculation of the degree of pyritization (DOP) in the sulfur-rich intervals (Table 8). The DOP parameter is defined as the ratio between pyrite-Fe and total reactive $\mathrm{Fe}$ (Berner, 1970; Raiswell and Berner, 1985). Total reactive iron $\left(\mathrm{Fe}_{\mathrm{R}}\right)$ includes iron extractable by hot $\mathrm{HCl}\left(\mathrm{Fe}_{\mathrm{HCl}}\right)$ and pyriteiron $\left(\mathrm{Fe}_{\mathrm{py}}\right)$ calculated from the content of non-organic and non-acidvolatile sulfur (negligible in these samples). Concentration of total iron $\left(\mathrm{Fe}_{\mathrm{tot}}\right)$ was high (6-30 wt\%) in samples from Lithofacies B, C, and $\mathrm{D}$, reflecting the origin of the clays as tropical weathering products. $\mathrm{Fe}_{\mathrm{HCl}}$ was generally low $(0.1-4.5 \mathrm{wt} \%)$ in the pyrite-containing intervals of Lithofacies B and C. Lowest values were found in the gray clay of Lithofacies $\mathrm{C}$ immediately below the black, organic-rich clay. DOP was seen to drop from values close to $100 \%$ in the black clay and upper part of the gray clay to much lower values immediately above the reduction front (Table 8, Fig. 6).

\section{DISCUSSION}

In the Leg 144 guyots, the timing of initial transgressions covers a period of more than 65 m.y., from late Paleocene (Limalok) and Campanian (Wodejebato), to Aptian (MIT and Takuyo-Daisan) ages. 

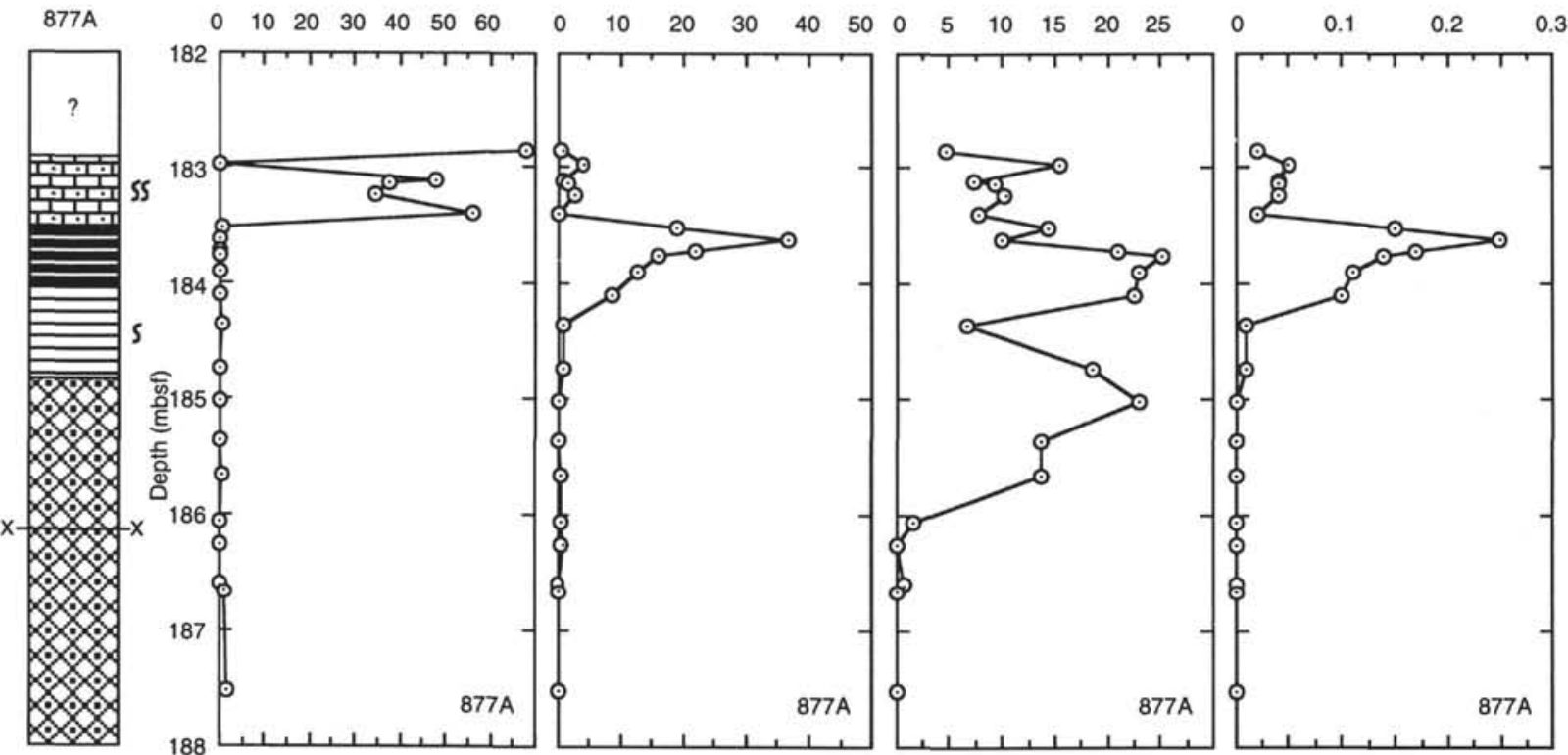

$\mathrm{CaCO}_{3}(\mathrm{wt} \%)$

TOC (wt\%)

$\mathrm{S}(\mathrm{wt} \%)$

$\mathrm{N}(\mathrm{wt} \%)$

$878 \mathrm{~A}$
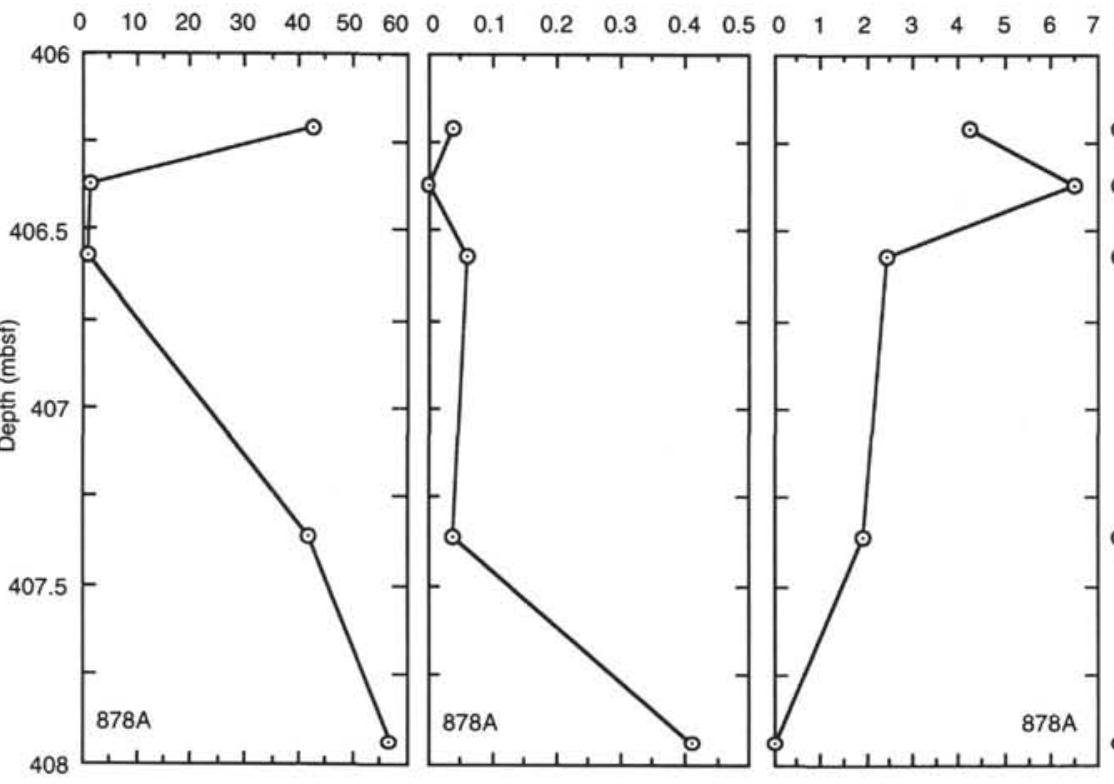

$\begin{array}{llllll}0 & 0.1 & 0.2 & 0.3 & 0.4 & 0.5\end{array}$

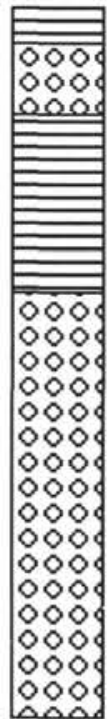

Legend

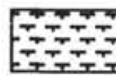

Pelagic ooze

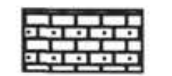

Argillaceous and/or pyritic grainstone or packstone (Lithofacies A)

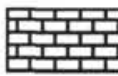

\section{Platform carbonate}

Black clay, pyritic (Lithofacies B)

00004 Breccia

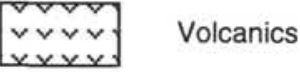

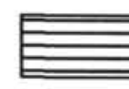

Mottled clay, gray or red (Lithofacies C)

Bioturbation

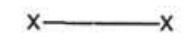

Clay/claystone with relict structures of weathered basalt (Lithofacies D)

Gray/red boundary in clay

Figure 2 (continued). 
Table 3. Results of geochemical screening, ITP sequence.

\begin{tabular}{|c|c|c|c|c|c|c|}
\hline $\begin{array}{l}\text { Core, section, } \\
\text { interval }(\mathrm{cm})\end{array}$ & $\begin{array}{l}\text { Depth } \\
\text { (mbsf) }\end{array}$ & Lithology & $\begin{array}{l}\mathrm{CaCO}_{3} \\
(\mathrm{wt} \%)\end{array}$ & $\begin{array}{c}\text { TOC } \\
(w t \%)\end{array}$ & $\underset{(w t \%)}{N}$ & $\begin{array}{c}S \\
(w t \%)\end{array}$ \\
\hline $\begin{array}{l}144-871 \mathrm{C}- \\
\text { 3IR-CC, } 44-49 \\
32 \mathrm{R}-1,16-20 \\
32 \mathrm{R}-1,41-42 \\
32 \mathrm{R}-1,44-49 \\
32 \mathrm{R}-1,52-53 \\
32 \mathrm{R}-1,53-54 \\
32 \mathrm{R}-1,58-60 \\
32 \mathrm{R}-1,68-69 \\
32 \mathrm{R}-1,82-83 \\
\text { 32R-1, 98-99 } \\
32 \mathrm{R}-1,125-126 \\
32 \mathrm{R}-1,143-144 \\
32 \mathrm{R}-2,55-56 \\
32 \mathrm{R}-3,75-76 \\
\text { 32R-4, } 94-96\end{array}$ & $\begin{array}{l}412.80 \\
422.66 \\
422.91 \\
422.94 \\
423.02 \\
423.03 \\
423.08 \\
423.18 \\
423.32 \\
423.48 \\
423.75 \\
423.93 \\
424.55 \\
426.25 \\
427.94\end{array}$ & $\begin{array}{l}\text { Clay, black } \\
\text { Grainstone } \\
\text { Clay, black } \\
\text { Clay, gray } \\
\text { Clay, gray } \\
\text { Clay, gray } \\
\text { Clay, gray } \\
\text { Clay, gray } \\
\text { Clay, gray } \\
\text { Clay, gray } \\
\text { Clay, gray } \\
\text { Clay, red } \\
\text { Clay, gray } \\
\text { Clay, red } \\
\text { Clay, red }\end{array}$ & $\begin{array}{r}7.33 \\
96.57 \\
10.42 \\
73.60 \\
56.91 \\
22.16 \\
13.83 \\
0.92 \\
85.50 \\
56.90 \\
0.83 \\
2.90 \\
13.54 \\
0.08 \\
0.58\end{array}$ & $\begin{array}{r}12.48 \\
0.31 \\
10.21 \\
4.53 \\
0.87 \\
2.32 \\
1.08 \\
0.57 \\
0.00 \\
0.00 \\
0.34 \\
0.17 \\
1.21 \\
0.00 \\
0.00\end{array}$ & $\begin{array}{l}0.09 \\
0.01 \\
0.14 \\
0.09 \\
0.02 \\
0.03 \\
0.01 \\
0.01 \\
0.01 \\
0.01 \\
0.00 \\
0.01 \\
0.01 \\
0.00 \\
0.00\end{array}$ & $\begin{array}{r}3.29 \\
0.61 \\
12.63 \\
3.29 \\
3.20 \\
11.54 \\
7.50 \\
8.30 \\
1.64 \\
0.60 \\
1.48 \\
0.07 \\
1.94 \\
0.00 \\
0.01\end{array}$ \\
\hline $\begin{array}{l}\text { I44-873A- } \\
10 R-1,107-118 \\
11 \mathrm{R}-1,28-34 \\
11 \mathrm{R}-1,66-76 \\
11 \mathrm{R}-1,98-115 \\
11 \mathrm{R}-1,130-136 \\
11 \mathrm{R}-2,0-17 \\
11 \mathrm{R}-2,17-22 \\
11 \mathrm{R}-2,91-104 \\
\text { 12R-1, 28-30 }\end{array}$ & $\begin{array}{l}137.67 \\
146.48 \\
146.86 \\
147.18 \\
147.50 \\
147.66 \\
147.83 \\
148.57 \\
156.18\end{array}$ & $\begin{array}{l}\text { Packstone } \\
\text { Grainstone } \\
\text { Grainstone } \\
\text { Packstone } \\
\text { Grainstone } \\
\text { Packstone } \\
\text { Chalk } \\
\text { Grainstone } \\
\text { Clay, red }\end{array}$ & $\begin{array}{r}97.70 \\
96.00 \\
97.00 \\
86.60 \\
85.80 \\
80.10 \\
65.70 \\
97.50 \\
0.20\end{array}$ & $\begin{array}{l}0.28 \\
0.24 \\
0.18 \\
2.44 \\
1.26 \\
1.47 \\
2.14 \\
0.18 \\
0.08\end{array}$ & $\begin{array}{l}0.02 \\
0.02 \\
0.02 \\
0.06 \\
0.05 \\
0.05 \\
0.10 \\
0.02 \\
0.01\end{array}$ & $\begin{array}{l}0.00 \\
0.35 \\
0.00 \\
0.49 \\
0.61 \\
0.45 \\
0.28 \\
0.07 \\
0.08\end{array}$ \\
\hline $\begin{array}{l}144-874 \mathrm{~B} \\
21 \mathrm{R}-1,0-5 \\
21 \mathrm{R}-1,13-14 \\
21 \mathrm{R}-1,19-20 \\
21 \mathrm{R}-1,23-24 \\
21 \mathrm{R}-1,25-27 \\
21 \mathrm{R}-1,35-36 \\
21 \mathrm{R}-1,44-45 \\
21 \mathrm{R}-1,74-75 \\
21 \mathrm{R}-1,93-94 \\
21 \mathrm{R}-1,112-113 \\
21 \mathrm{R}-1,125-126 \\
21 \mathrm{R}-1,135-136 \\
21 \mathrm{R}-1,140-150 \\
21 \mathrm{R}-2,32-33 \\
21 \mathrm{R}-2,134-135 \\
22 \mathrm{R}-2,140-150\end{array}$ & $\begin{array}{l}162.82 \\
162.93 \\
162.99 \\
163.03 \\
163.05 \\
163.15 \\
163.24 \\
163.54 \\
163.73 \\
163.92 \\
164.05 \\
164.15 \\
164.20 \\
164.62 \\
165.64 \\
175.30\end{array}$ & $\begin{array}{l}\text { Clay, Black, pyritic } \\
\text { Clay, black, pyritic } \\
\text { Clay, black, pyritic } \\
\text { Clay, black, pyritic } \\
\text { Clay, black, pyritic } \\
\text { Clay, black, pyritic } \\
\text { Clay, black, pyritic } \\
\text { Clay, gray, pyritic } \\
\text { Clay, gray, pyritic } \\
\text { Clay, gray, pyritic } \\
\text { Clay, red } \\
\text { Clay, red } \\
\text { Clay, red } \\
\text { Clay, red } \\
\text { Clay, red } \\
\text { Clay, red }\end{array}$ & $\begin{array}{l}0.20 \\
0.17 \\
0.25 \\
0.25 \\
0.25 \\
0.58 \\
0.83 \\
0.72 \\
0.25 \\
0.25 \\
0.25 \\
0.25 \\
0.08 \\
0.07 \\
0.08 \\
0.08\end{array}$ & $\begin{array}{l}9.23 \\
5.04 \\
2.74 \\
8.64 \\
6.03 \\
4.73 \\
1.12 \\
0.69 \\
0.06 \\
1.87 \\
0.00 \\
0.07 \\
0.00 \\
\mathrm{ND} \\
1.44 \\
0.03\end{array}$ & $\begin{array}{l}0.09 \\
0.06 \\
0.03 \\
0.07 \\
\text { ND } \\
0.05 \\
0.00 \\
0.00 \\
0.00 \\
0.00 \\
0.00 \\
0.00 \\
0.00 \\
\text { ND } \\
0.01 \\
0.00\end{array}$ & $\begin{array}{r}16.16 \\
17.13 \\
17.07 \\
16.05 \\
13.45 \\
17.87 \\
13.77 \\
16.55 \\
3.81 \\
3.14 \\
0.01 \\
0.00 \\
0.00 \\
\text { ND } \\
0.57 \\
0.01\end{array}$ \\
\hline 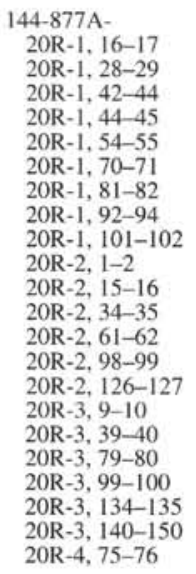 & $\begin{array}{l}182.86 \\
182.98 \\
183.12 \\
183.14 \\
183.24 \\
183.40 \\
183.51 \\
183.62 \\
183.71 \\
183.76 \\
183.90 \\
184.09 \\
184.36 \\
184.73 \\
185.01 \\
185.36 \\
185.66 \\
186.06 \\
186.26 \\
186.61 \\
186.67 \\
187.52\end{array}$ & $\begin{array}{l}\text { Grainstone } \\
\text { Clay, black } \\
\text { Grainstone } \\
\text { Grainstone } \\
\text { Grainstone } \\
\text { Grainstone } \\
\text { Clay, black, peaty } \\
\text { Clay, black, peaty } \\
\text { Clay, black, peaty } \\
\text { Clay, black, peaty } \\
\text { Clay, black, peaty } \\
\text { Clay, black, peaty } \\
\text { Clay, gray } \\
\text { Clay, gray } \\
\text { Clay, gray } \\
\text { Clay, gray } \\
\text { Clay, gray } \\
\text { Clay, gray } \\
\text { Clay, red } \\
\text { Clay, red } \\
\text { Clay, red } \\
\text { Clay, red }\end{array}$ & $\begin{array}{r}67.89 \\
0.25 \\
48.06 \\
37.57 \\
34.40 \\
55.98 \\
0.50 \\
0.25 \\
0.25 \\
0.17 \\
0.33 \\
0.33 \\
0.75 \\
0.25 \\
0.33 \\
0.33 \\
0.50 \\
0.33 \\
0.33 \\
0.25 \\
0.92 \\
1.60\end{array}$ & $\begin{array}{r}0.72 \\
4.13 \\
1.03 \\
1.78 \\
2.80 \\
0.29 \\
18.96 \\
36.51 \\
21.85 \\
15.95 \\
12.63 \\
8.76 \\
0.92 \\
1.06 \\
0.11 \\
0.10 \\
0.48 \\
0.51 \\
0.76 \\
0.05 \\
0.07 \\
0.09\end{array}$ & $\begin{array}{l}0.02 \\
0.05 \\
0.04 \\
0.04 \\
0.04 \\
0.02 \\
0.15 \\
0.25 \\
0.17 \\
0.14 \\
0.11 \\
0.10 \\
0.01 \\
0.01 \\
0.00 \\
0.00 \\
0.00 \\
0.00 \\
0.00 \\
0.00 \\
0.00 \\
0.00\end{array}$ & $\begin{array}{r}4.75 \\
15.44 \\
7.42 \\
9.36 \\
10.31 \\
7.78 \\
14.37 \\
9.97 \\
20.96 \\
25.19 \\
22.94 \\
22.52 \\
6.72 \\
18.59 \\
23.03 \\
13.65 \\
13.65 \\
1.70 \\
0.13 \\
0.73 \\
0.11 \\
0.00\end{array}$ \\
\hline $\begin{array}{c}144-878 \mathrm{~A}- \\
44 \mathrm{M}-1,11-14 \\
44 \mathrm{M}-1,27-28 \\
44 \mathrm{M}-1,47-49 \\
44 \mathrm{M}-1,126-128 \\
44 \mathrm{M}-2,34-36\end{array}$ & $\begin{array}{l}406.21 \\
406.37 \\
406.57 \\
407.36 \\
407.94\end{array}$ & $\begin{array}{l}\text { Volcanic breccia } \\
\text { Volcanic breccia } \\
\text { Volcanic breccia } \\
\text { Volcanic breccia } \\
\text { Volcanic breccia }\end{array}$ & $\begin{array}{r}42.48 \\
1.50 \\
0.83 \\
41.90 \\
56.98\end{array}$ & $\begin{array}{l}0.04 \\
0.00 \\
0.06 \\
0.04 \\
0.41\end{array}$ & $\begin{array}{l}0.00 \\
0.00 \\
0.00 \\
0.00 \\
0.00\end{array}$ & $\begin{array}{l}4.23 \\
6.52 \\
2.43 \\
1.94 \\
0.00\end{array}$ \\
\hline $\begin{array}{l}\text { 144-879A- } \\
16 \mathrm{R}-1,113-115 \\
17 \mathrm{R}-1,74-76 \\
17 \mathrm{R}-1,91-95 \\
17 \mathrm{R}-2,24-25 \\
17 \mathrm{R}-2,48-49 \\
17 \mathrm{R}-2,71-72 \\
18 \mathrm{R}-1,4-5 \\
18 \mathrm{R}-1,33-34 \\
18 \mathrm{R}-1,43-44\end{array}$ & $\begin{array}{l}141.93 \\
151.14 \\
151.31 \\
152.14 \\
152.38 \\
152.61 \\
160.14 \\
160.43 \\
160.53\end{array}$ & $\begin{array}{l}\text { Wackestone } \\
\text { Sand, clayey, dark } \\
\text { Sand, clayey, dark } \\
\text { Sandstone } \\
\text { Conglomerate } \\
\text { Clay, green-gray } \\
\text { Argillaceous limestone } \\
\text { Sand, calcareous } \\
\text { Clay, greenish }\end{array}$ & $\begin{array}{r}85.00 \\
17.50 \\
5.50 \\
15.70 \\
63.30 \\
4.00 \\
94.40 \\
88.00 \\
70.40\end{array}$ & $\begin{array}{l}0.21 \\
1.90 \\
0.87 \\
1.67 \\
0.11 \\
0.00 \\
0.22 \\
0.25 \\
0.20\end{array}$ & $\begin{array}{l}0.00 \\
0.03 \\
0.02 \\
0.02 \\
0.00 \\
0.00 \\
0.00 \\
0.01 \\
0.01\end{array}$ & $\begin{array}{l}0.83 \\
3.71 \\
2.07 \\
0.65 \\
0.03 \\
0.00 \\
0.00 \\
0.00 \\
0.23\end{array}$ \\
\hline
\end{tabular}

Notes: $\mathrm{CaCO}_{3}=$ carbonate carbon calculated as calcium carbonate, $\mathrm{TOC}=$ total organic carbon, $\mathrm{N}=$ nitrogen, and $\mathrm{S}=$ total sulfur. $\mathrm{ND}=$ no determination. 

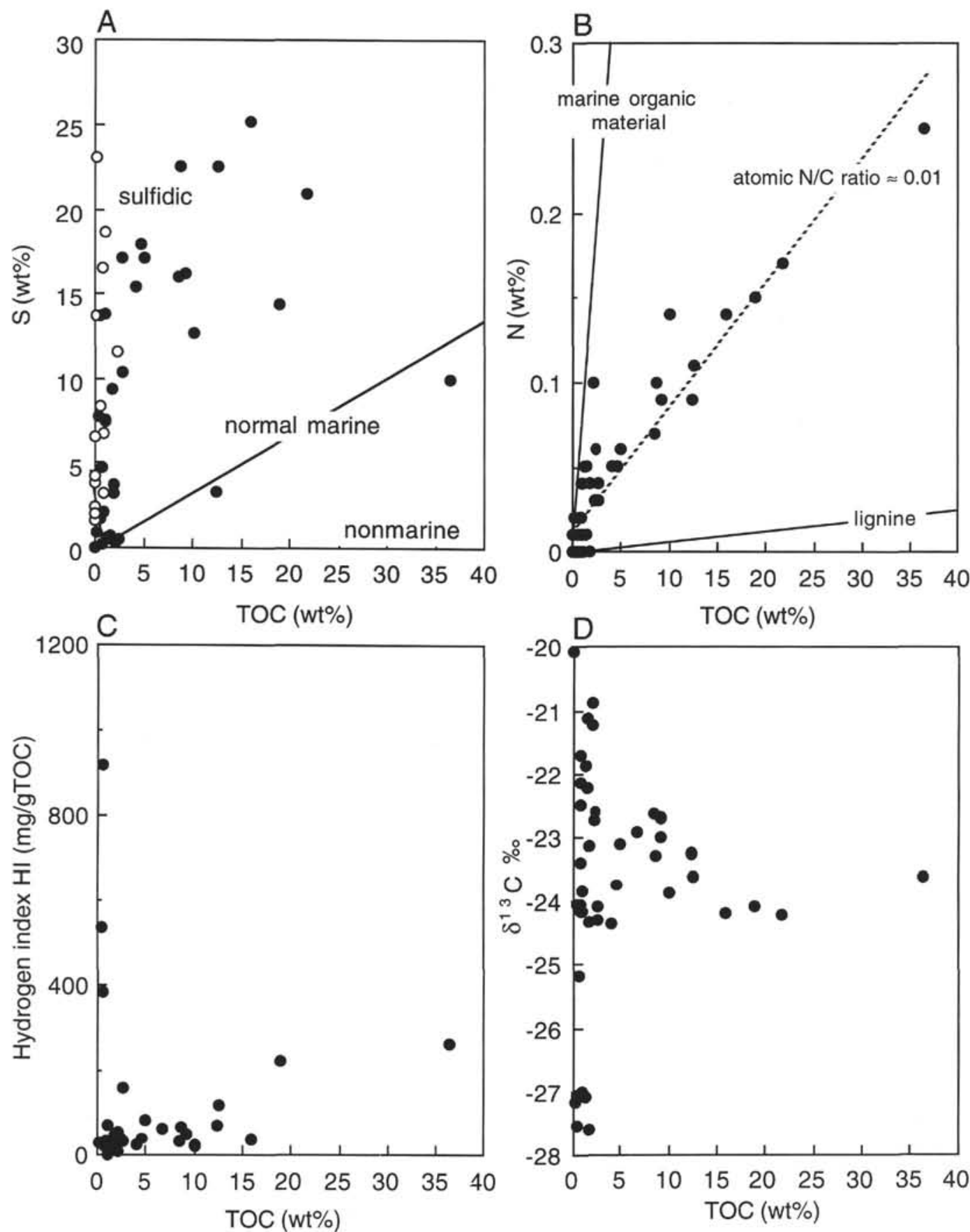

Figure 3. Crossplots of selected geochemical parameters vs. total organic carbon (TOC) for the ITP sequence in Limalok, Lo-En, Wodejebato, MIT, and Takuyo-Daisan guyots. A. Total sulfur (S) vs. TOC. Solid circles = primary sulfur in black clay, and open circles = migrated sulfur in mottled clay. The "normal marine" line with a slope of 0.36 refers to the empiric S/TOC relationship from Berner (1984). B. Total nitrogen (N) vs. TOC. The good correlation between N and $\mathrm{C}$ indicates the nitrogen to be dominantly organic. C. Rock Eval hydrogen index (HI) vs. TOC. D. Carbon isotope composition $\left(\delta^{13} \mathrm{C} \%\right.$ PDB) vs. TOC.

Nevertheless, the lithologic and geochemical development associated with these transgressions had several traits in common: (1) subaerial weathering and soil formation of volcanics below the transgressive surface, (2) deep truncation of pedogenic profiles before transgression, (3) accumulation of both marine and terrestrial organic matter at the transgressive surface, (4) strong sulfur enrichment of rocks at and below the transgressive surface, and (5) gradual shift from pyritebearing argillaceous rocks above the transgressive surface to pure calcareous rocks of platform facies. Of these five characteristics, this study has primarily focused on the remarkable sulfur enrichment seen at the transgression surface.
Table 4. Chemofacies types in the ITP sequence.

\begin{tabular}{lcrrrr}
\hline \multicolumn{1}{c}{ Lithology } & $\begin{array}{l}\mathrm{CaCO}_{3} \\
(\mathrm{wt} \%)\end{array}$ & $\begin{array}{c}\mathrm{TOC} \\
(\mathrm{wt} \%)\end{array}$ & $\begin{array}{c}\mathrm{S} \\
(\mathrm{wt} \%)\end{array}$ & $\begin{array}{c}\mathrm{Fe} \\
(\mathrm{wt} \%)\end{array}$ & Chemofacies \\
\hline Argillaceous grainstone & $>50$ & $<2$ & $<5$ & $<5$ & Facies A \\
Clay, black & $<1$ & $2-36$ & $12-26$ & $10-30$ & Facies B \\
Clay/claystone, gray & $<1$ & $<2$ & $2-23$ & $10-35$ & Facies C \\
$\begin{array}{l}\text { Clay/claystone, red } \\
\text { Weathered basalt }\end{array}$ & $<2$ & $<2$ & $<1$ & $10-30$ & Facies D \\
\hline
\end{tabular}

Notes: $\mathrm{CaCO}_{3}=$ carbon content calculated as calcium carbonate, $\mathrm{TOC}=$ total organic carbon, $\mathrm{S}=$ total sulfur, and $\mathrm{Fe}=$ total iron. 
Table 5. Organic geochemical screening data.

\begin{tabular}{|c|c|c|c|c|c|c|c|c|}
\hline $\begin{array}{l}\text { Core, section, } \\
\text { interval }(\mathrm{cm})\end{array}$ & $\begin{array}{l}\text { Depth } \\
\text { (mbsf) }\end{array}$ & Lithology & $\begin{array}{l}\text { TOC } \\
\text { (wt\%) }\end{array}$ & $\begin{array}{c}\mathrm{S}_{1} \\
\text { (mg HCg) }\end{array}$ & $\begin{array}{c}\mathrm{S}_{2} \\
\text { (mg HCg) }\end{array}$ & $\begin{array}{c}\mathrm{HI} \\
(\mathrm{mg} \mathrm{HC} / \mathrm{g})\end{array}$ & $\begin{array}{l}\mathrm{T}_{\max } \\
\left({ }^{\circ} \mathrm{C}\right)\end{array}$ & $\begin{array}{l}\delta^{13} \mathrm{C}_{\mathrm{OM}} \\
\left(\%_{\circ} \mathrm{PDB}\right)\end{array}$ \\
\hline \multicolumn{9}{|l|}{$144-871 \mathrm{C}-$} \\
\hline 3IR-CC, $44-49$ & 412.80 & Clay, black & 12.48 & 0.48 & 2.95 & 69 & 428 & -23.26 \\
\hline $32 \mathrm{R}-1,41-42$ & 422.91 & Clay, black & 10.21 & 1.10 & 1.98 & 22 & 415 & -23.87 \\
\hline $32 \mathrm{R}-1,44-49$ & 422.95 & Clay, gray & 2.12 & 0.00 & 0.20 & 9 & 426 & ND \\
\hline $32 \mathrm{R}-1,52-53$ & 423.02 & Clay, gray & 0.87 & 0.20 & 0.52 & 26 & 415 & -22.15 \\
\hline $32 \mathrm{R}-1,53-54$ & 423.03 & Clay, gray & 2.32 & ND & ND & ND & ND & -22.75 \\
\hline $32 \mathrm{R}-1,58-60$ & 423.08 & Clay, gray & 1.08 & 0.10 & 0.59 & 70 & 407 & ND \\
\hline $32 R-1,68-69$ & 423.18 & Clay, gray & 0.57 & 0.54 & 3.56 & 383 & 446 & -24.04 \\
\hline \multicolumn{9}{|l|}{ 144-873C- } \\
\hline $11 R-1,98-115$ & 147.18 & Packstone & 2.44 & 1.82 & 1.32 & 59 & ND & -22.61 \\
\hline $11 \mathrm{R}-1,102-104$ & 147.22 & Packstone & 1.60 & 0.02 & 0.47 & 29 & 418 & -22.23 \\
\hline $11 \mathrm{R}-1,126-138$ & 147.46 & Grainstone & 0.94 & 0.01 & 0.31 & 33 & 426 & -21.71 \\
\hline $11 \mathrm{R}-1,130-136$ & 147.50 & Grainstone & 1.26 & ND & ND & ND & ND & ND \\
\hline $11 R-2,0-17$ & 147.70 & Packstone & 1.47 & ND & ND & ND & ND & -21.89 \\
\hline $11 \mathrm{R}-2,13-16$ & 147.83 & Grainstone & ND & 0.02 & 0.32 & 31 & 425 & -21.22 \\
\hline $11 \mathrm{R}-2,16-21$ & 147.86 & Grainstone & 2.23 & 0.06 & 0.73 & 33 & 424 & -20.89 \\
\hline $11 \mathrm{R}-2,17-22$ & 147.87 & Chalk, clayey & 2.14 & 0.22 & 1.55 & 51 & 426 & -21.24 \\
\hline \multicolumn{9}{|l|}{ 144-874B- } \\
\hline $21 \mathrm{R}-1,0-5$ & 162.80 & Clay, black & 9.23 & 3.17 & 4.37 & 47 & 386 & -22.70 \\
\hline $21 \mathrm{R}-1,13-14$ & 162.83 & Clay, black & 5.04 & 1.12 & 3.75 & 79 & 475 & -23.12 \\
\hline $21 \mathrm{R}-1,19-20$ & 162.99 & Clay, black & 2.74 & 0.82 & 5.40 & 157 & 454 & -24.30 \\
\hline $21 \mathrm{R}-1,23-24$ & 163.03 & Clay, black & 8.64 & 2.03 & 2.67 & 31 & 384 & -22.62 \\
\hline $21 \mathrm{R}-1,25-27$ & 163.05 & Clay, black & 6.76 & 1.00 & 3.99 & 59 & 394 & -22.93 \\
\hline $21 \mathrm{R}-1,35-36$ & 163.15 & Clay, black & 4.73 & 1.60 & 2.32 & 38 & 399 & -23.75 \\
\hline 2 IR-1, 44-45 & 163.24 & Clay, black & 1.12 & 2.20 & 6.68 & 596 & 339 & -27.01 \\
\hline $21 \mathrm{R}-1,74-75$ & 163.54 & Clay. gray & 0.69 & 0.78 & 6.69 & 970 & 466 & -27.54 \\
\hline $21 \mathrm{R}-1,112-113$ & 163.92 & Clay, gray & 1.87 & 0.95 & 1.13 & 60 & 365 & -27.60 \\
\hline $21 \mathrm{R}-2,134-135$ & 165.64 & Clay, red & 1.44 & 0.60 & 0.56 & 39 & 467 & -27.09 \\
\hline \multicolumn{9}{|l|}{$144-877 \mathrm{~A}-$} \\
\hline $20 \mathrm{R}-1 ; 16-17$ & 182.86 & Grainstone & 0.72 & 0.04 & 0.28 & 19 & 470 & ND \\
\hline $20 \mathrm{R}-1,28-29$ & 182.98 & Clay, black & 4.13 & 0.09 & 0.87 & 24 & 414 & -24.34 \\
\hline $20 \mathrm{R}-1,42-44$ & 183.12 & Grainstone & 2.63 & 0.11 & 0.95 & 36 & 422 & -24.15 \\
\hline $20 \mathrm{R}-1,42-44$ & 183.12 & Grainstone & 2.63 & 0.11 & 0.95 & 36 & 422 & ND \\
\hline $20 \mathrm{R}-1,44-45$ & 183.14 & Grainstone & 1.78 & 0.39 & 1.30 & 43 & 412 & -24.33 \\
\hline $20 \mathrm{R}-1,54-55$ & 183.24 & Grainstone & 2.80 & 0.46 & 1.38 & 32 & 408 & -24.08 \\
\hline $20 \mathrm{R}-1,70-71$ & 183.40 & Packstone & 0.29 & 0.17 & 0.46 & 27 & 537 & ND \\
\hline $20 \mathrm{R}-1,81-82$ & 183.51 & Clay, black & 18.96 & 2.59 & 31.59 & 222 & 425 & -24.08 \\
\hline $20 \mathrm{R}-1,92-94$ & 183.62 & Clay, black & 36.51 & 2.95 & 40.56 & 260 & 420 & -23.63 \\
\hline $20 \mathrm{R}-1,101-102$ & 183.71 & Clay, black & 21.85 & ND & ND & ND & ND & -24.22 \\
\hline $20 \mathrm{R}-2,1-2$ & 183.81 & Clay, black & 15.95 & 1.56 & 7.05 & 36 & 396 & -24.19 \\
\hline $20 \mathrm{R}-2,15-16$ & 183.95 & Clay, black & 12.63 & 1.43 & 9.63 & 116 & 416 & -23.64 \\
\hline $20 \mathrm{R}-2,34-35$ & 184.14 & Clay, black & 8.76 & 1.29 & 4.04 & 64 & 397 & -23.31 \\
\hline $20 \mathrm{R}-2,53-55$ & 184.32 & Clay, grey & 0.92 & ND & ND & ND & ND & -23.41 \\
\hline $20 \mathrm{R}-2,61-62$ & 184.42 & Clay, grey & 0.92 & ND & ND & ND & ND & -24.06 \\
\hline $20 \mathrm{R}-2,98-99$ & 184.79 & Clay, gray & 1.06 & 0.07 & 0.00 & 0 & ND & -23.85 \\
\hline $20 \mathrm{R}-3,9-10$ & 185.34 & Clay, gray & 0.10 & 0.36 & 1.32 & ND & 459 & ND \\
\hline $20 \mathrm{R}-3,39-40$ & 185.64 & Clay, gray & 0.48 & 0.06 & ND & ND & ND & -27.16 \\
\hline $20 \mathrm{R}-3,79-80$ & 186.04 & Clay, gray & 0.51 & 0.41 & 1.61 & ND & 454 & -27.07 \\
\hline $20 \mathrm{R}-3,99-100$ & 186.24 & Clay, red & 0.76 & 0.23 & ND & ND & ND & -25.19 \\
\hline \multicolumn{9}{|l|}{$144-879 \mathrm{~A}-$} \\
\hline $16 \mathrm{R}-1,113-115$ & 141.93 & Wackestone & 0.21 & ND & ND & ND & ND & -20.07 \\
\hline $17 \mathrm{R}-1,74-76$ & 151.16 & Clay, black & 1.90 & 0.16 & 0.74 & 22 & 406 & -23.14 \\
\hline $17 \mathrm{R}-1,91-95$ & 151.31 & Clay, black & 0.87 & ND & ND & ND & ND & -22.49 \\
\hline $17 \mathrm{R}-2,24-25$ & 152.14 & Clay, black & 1.67 & 0.22 & 0.43 & 28 & 411 & -21.13 \\
\hline
\end{tabular}

Notes: $\mathrm{TOC}=$ total organic carbon from Table $3 . \mathrm{S}_{1}$ and $\mathrm{S}_{2}=\mathrm{mg}$ hydrocarbon/gram of rock. $\mathrm{HI}=$ hydrogen index (mg hydrocarbon/gram organic carbon). $\mathrm{T}_{\text {max }}=\mathrm{maximal} \mathrm{S}_{2}$ pyrolysis temperature (in ${ }^{\circ}$ Celsius). $\delta^{13} \mathrm{C}_{\mathrm{OM}}=$ carbon isotope composition of organic matter. $\mathrm{ND}=$ no determination.

Figure 4. Kerogen typing and maturation of organic matter in the ITP sequence at Limalok, Wodejebato, and Takuyo-Daisan guyots. The data demonstrate that most of the organic material is of kerogen type III (or strongly degraded type II) and is thermally immature to marginally mature.

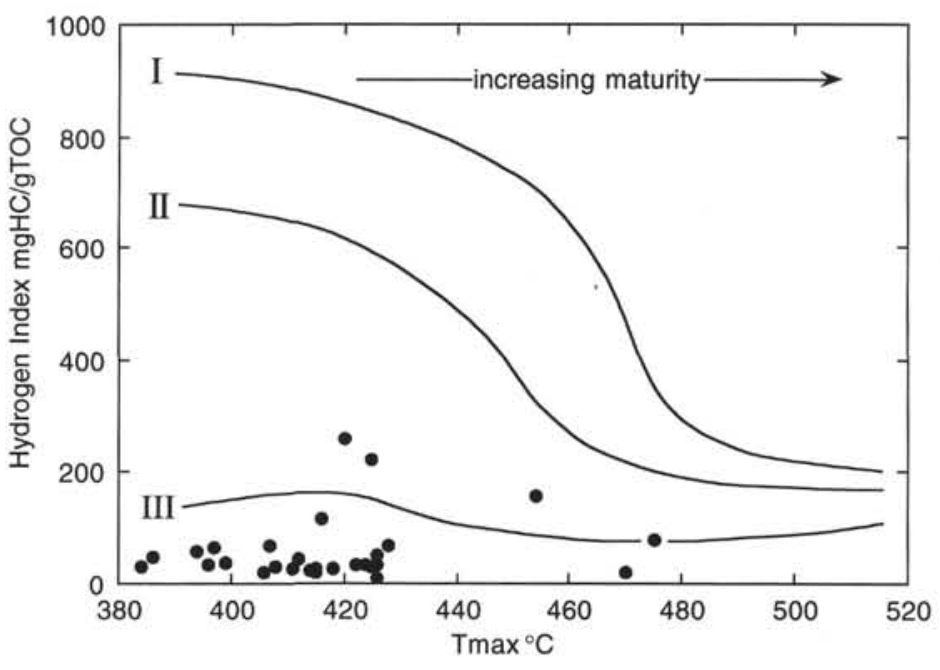




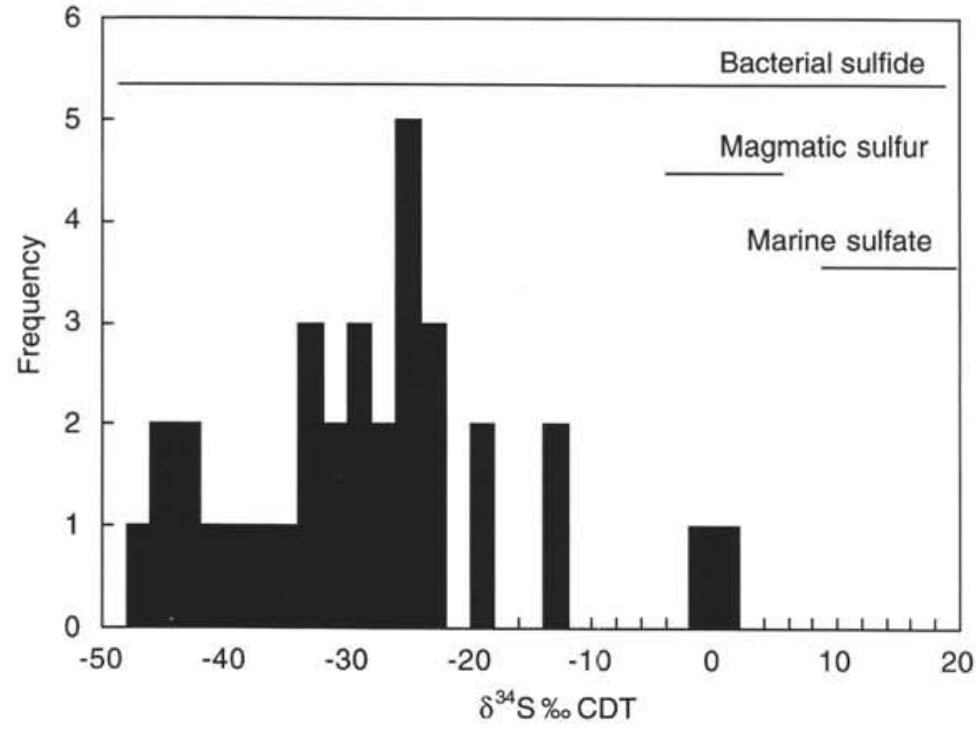

Figure 5. Frequency distribution of sulfur isotope composition $\left(8^{34} \mathrm{~S} \% \mathrm{CDT}\right)$ of pyrite and marcasite from the ITP sequence at Limalok, Wodejebato, MIT, and Takuyo-Daisan guyots. General ranges for typical isotopic compositions are from Hoefs (1987).

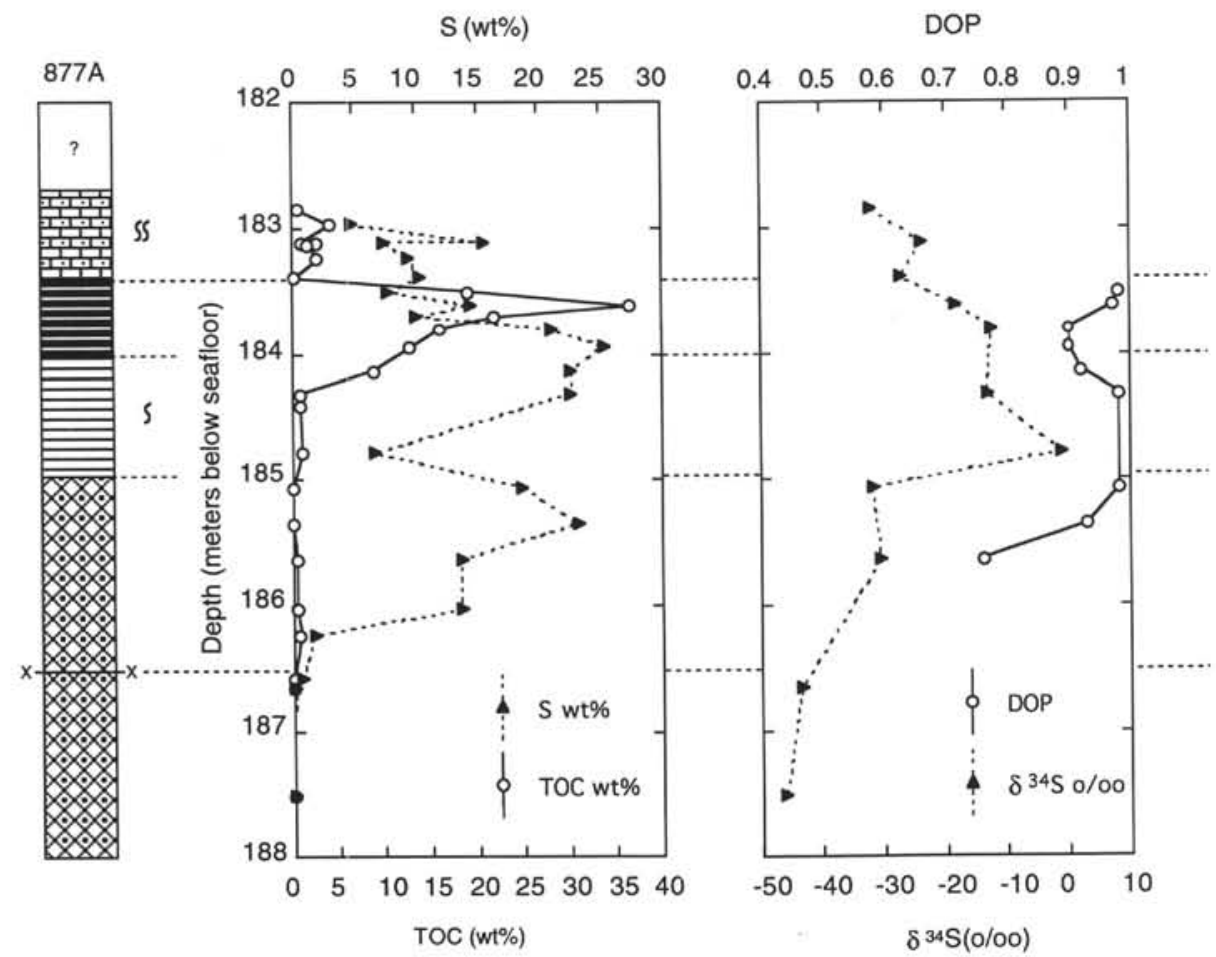

Figure 6. Detailed profiles of the ITP sequence in Hole $877 \mathrm{~A}$ at the Wodejebato Guyot showing total organic carbon (TOC), sulfur isotope composition ( ${ }^{34} \mathrm{~S} \%$ CDT), total sulfur (S), and degree of pyritization (DOP). Lithologic units as in Figure 1.

In Premoli Silva, Haggerty, Rack, et al. (1993), the sulfur-rich black clay deposits of Sites 871,874 , and 877 were interpreted as marginal marine deposits formed in sheltered, low-energy lagoons. It was also suggested that microbial reduction of seawater sulfate was the most important sulfur-fixing process in these deposits. The present study has not provided data in conflict with these conclusions. The strong sulfur enrichment found in the ITP deposits at the Marshall Island guyots does, however, raise a series of questions: (1) Was the sulfur-fixing mechanism hydrothermal or biological? (2) If only biological processes were responsible, how could sulfur enrichment reach such high levels? (3) What was the driving mechanism of the sulfur enrichment in the TOC-poor deposits of Lithofacies B and C below the organic-rich clays of Lithofacies A?

The sulfur enrichment is clearly confined both upward and downward. In the lithofacies association characteristic of the ITP sequence, only lithofacies A, B, and C contain sulfur, predominantly in the form of pyrite. The lower boundary to sulfur free clays is marked by a color change from gray to red, whereas the platform carbonates above the ITP only contain pyrite in sheltered microenvironments (e.g., lithologic Subunit IIIB at Site 873; Premoli Silva, Haggerty, Rack, et al., 1993).

The widespread indications of well-developed soil profiles at the bottom of the ITP sequence argue against a hydrothermal origin for 
Table 6. Organic extraction data.

\begin{tabular}{|c|c|c|c|c|c|c|c|}
\hline $\begin{array}{l}\text { Core, section } \\
\text { interval }(\mathrm{cm})\end{array}$ & Depth & Lithology & $\begin{array}{l}\text { TOC } \\
\text { (wt\%) }\end{array}$ & $\begin{array}{c}\text { Extract } \\
\text { (mg/g TOC) }\end{array}$ & $\begin{array}{l}\text { Aliphatics } \\
\text { (wt\%) }\end{array}$ & $\begin{array}{c}\text { Aromatics } \\
\text { (wt } \%)\end{array}$ & $\begin{array}{c}\text { Polar } \\
\text { components } \\
\text { (wt\%) }\end{array}$ \\
\hline \multicolumn{8}{|l|}{$144-$} \\
\hline $871 \mathrm{C}-32 \mathrm{R}-1,58-60$ & 423.08 & Clay, gray & 1.08 & 69.2 & 24 & 0 & 76 \\
\hline $873 \mathrm{~A}-11 \mathrm{R}-1,102-104$ & 147.22 & Grainstone & 1.60 & 64.7 & 0 & 0 & 100 \\
\hline $874 \mathrm{~B}-21 \mathrm{R}-1,0-5$ & 162.80 & Clay, black & 9.23 & 114.7 & 30 & 20 & 70 \\
\hline $874 \mathrm{~B}-21 \mathrm{R}-1.25-27$ & 163.05 & Clay, black & 6.76 & 68.9 & 10 & 20 & 70 \\
\hline $877 \mathrm{~A}-20 \mathrm{R}-1,92-94$ & 183.62 & Clay, black & 36.51 & 52.1 & 18 & 8 & 74 \\
\hline 877 A-20R-2, $15-16$ & 183.95 & Clay, black & 12.63 & 70.8 & 19 & 10 & 71 \\
\hline $877 \mathrm{~A}-20 \mathrm{R}-2,53-55$ & 184.32 & Clay, gray & 0.92 & n.d. & 12 & 24 & 63 \\
\hline $879 \mathrm{~A}-17 \mathrm{R}-1,74-76$ & 151.16 & Clay, black & 1.90 & 53.9 & 12 & 12 & 75 \\
\hline
\end{tabular}

Notes: TOC $=$ total organic carbon (from Table 3). Measurements in weight percent of total extract.

Table 7. Sulfur data from the ITP sequence.

\begin{tabular}{|c|c|c|c|c|c|c|c|}
\hline $\begin{array}{l}\text { Core, section, } \\
\text { interval }(\mathrm{cm})\end{array}$ & $\begin{array}{l}\text { Depth } \\
\text { (mbsf) }\end{array}$ & Lithology & TOC (wt\%) & $\underset{(w t \%)}{S}$ & $\underset{(\mathrm{mg} \mathrm{S} / \mathrm{g})}{\mathrm{S}_{\mathrm{org}}}$ & $\mathrm{S}_{\mathrm{org}} / \mathrm{S}_{\mathrm{tot}}$ & $\begin{array}{l}\delta^{34} S \\
(\% 0)\end{array}$ \\
\hline $\begin{array}{l}144-871 \mathrm{C}- \\
31 \mathrm{R}-\mathrm{CC}, 44-49 \\
32 \mathrm{R}-1,41-42 \\
32 \mathrm{R}-1,53-54 \\
32 \mathrm{R}-1,58-60 \\
32 \mathrm{R}-1,68-69 \\
32 \mathrm{R}-2,55-56\end{array}$ & $\begin{array}{l}412.80 \\
422.91 \\
423.03 \\
423.08 \\
423.18 \\
424.55\end{array}$ & $\begin{array}{l}\text { Clay, black } \\
\text { Clay, black } \\
\text { Clay, gray } \\
\text { Clay, gray } \\
\text { Clay, gray } \\
\text { Clay, gray }\end{array}$ & $\begin{array}{r}12.48 \\
10.21 \\
2.32 \\
1.08 \\
0.57 \\
0.01\end{array}$ & $\begin{array}{r}3.29 \\
12.63 \\
11.54 \\
7.50 \\
8.30 \\
1.94\end{array}$ & $\begin{array}{l}0.00 \\
0.00 \\
\text { ND } \\
0.00 \\
\text { ND } \\
\text { ND }\end{array}$ & $\begin{array}{l}0.00 \\
0.00 \\
\text { ND } \\
0.00 \\
\text { ND } \\
\text { ND }\end{array}$ & $\begin{array}{l}-25.6 \\
-29.0 \\
-37.5 \\
-33.9 \\
-26.9 \\
-30.0\end{array}$ \\
\hline $\begin{array}{l}144-873 \mathrm{~A}- \\
11 \mathrm{R}-1,126-138 \\
11 \mathrm{R}-2,16-21\end{array}$ & $\begin{array}{l}147.46 \\
147.86\end{array}$ & $\begin{array}{l}\text { Grainstone } \\
\text { Grainstone }\end{array}$ & $\begin{array}{l}0.94 \\
2.23\end{array}$ & $\begin{array}{l}0.61 \\
0.28\end{array}$ & $\begin{array}{l}0.00 \\
0.00\end{array}$ & $\begin{array}{l}0.00 \\
0.00\end{array}$ & $\begin{array}{r}-19.4 \\
1.7\end{array}$ \\
\hline $\begin{array}{l}\text { 144-874B- } \\
21 \mathrm{R}-1,0-5 \\
21 \mathrm{R}-1,13-14 \\
21 \mathrm{R}-1,19-20 \\
21 \mathrm{R}-1,25-27 \\
21 \mathrm{R}-1,44-45 \\
21 \mathrm{R}-1,74-75 \\
21 \mathrm{R}-1,112-113\end{array}$ & $\begin{array}{l}162.80 \\
162.83 \\
162.99 \\
163.05 \\
163.24 \\
163.54 \\
163.92\end{array}$ & $\begin{array}{l}\text { Clay, black } \\
\text { Clay, black } \\
\text { Clay, black } \\
\text { Clay, black } \\
\text { Clay, black } \\
\text { Clay, gray } \\
\text { Clay, gray }\end{array}$ & $\begin{array}{l}9.23 \\
5.04 \\
2.74 \\
6.76 \\
1.12 \\
0.69 \\
1.87\end{array}$ & $\begin{array}{r}16.16 \\
17.13 \\
17.07 \\
13.45 \\
13.77 \\
16.55 \\
3.14\end{array}$ & $\begin{array}{l}0.00 \\
0.00 \\
0.00 \\
0.00 \\
0.00 \\
0.00 \\
1.74\end{array}$ & $\begin{array}{l}0.00 \\
0.00 \\
0.00 \\
0.00 \\
0.00 \\
0.00 \\
0.06\end{array}$ & $\begin{array}{l}-25.3 \\
-23.9 \\
-24.3 \\
-26.0 \\
-29.0 \\
-25.9 \\
-40.0\end{array}$ \\
\hline $\begin{array}{l}144-877 \mathrm{~A}- \\
20 \mathrm{R}-1,16-17 \\
20 \mathrm{R}-1,42-44 \\
20 \mathrm{R}-1,42-44 \\
20 \mathrm{R}-1,70-71 \\
20 \mathrm{R}-1,92-94 \\
20 \mathrm{R}-2,1-2 \\
20 \mathrm{R}-2,53-55 \\
20 \mathrm{R}-2,98-99 \\
20 \mathrm{R}-2,126-127 \\
\text { 20R-3, 39-40 }\end{array}$ & $\begin{array}{l}182.86 \\
183.12 \\
183.12 \\
183.40 \\
183.62 \\
183.81 \\
184.32 \\
184.79 \\
185.07 \\
185.64\end{array}$ & $\begin{array}{l}\text { Grainstone } \\
\text { Grainstone } \\
\text { Grainstone } \\
\text { Packstone } \\
\text { Clay, black } \\
\text { Clay, black } \\
\text { Clay, gray } \\
\text { Clay, gray } \\
\text { Clay, gray } \\
\text { Clay, gray }\end{array}$ & $\begin{array}{r}0.72 \\
2.63 \\
2.63 \\
0.29 \\
36.51 \\
15.95 \\
0.92 \\
1.06 \\
0.11 \\
0.48\end{array}$ & $\begin{array}{r}4.75 \\
7.42 \\
7.42 \\
7.78 \\
9.97 \\
25.19 \\
6.72 \\
18.59 \\
23.03 \\
13.65\end{array}$ & $\begin{array}{r}0.00 \\
0.00 \\
0.00 \\
0.00 \\
22.78 \\
46.64 \\
0.00 \\
28.50 \\
0.00 \\
0.00\end{array}$ & $\begin{array}{l}0.00 \\
0.00 \\
0.00 \\
0.00 \\
0.23 \\
0.19 \\
0.00 \\
0.15 \\
0.00 \\
0.00\end{array}$ & $\begin{array}{l}-32.1 \\
-23.9 \\
-23.9 \\
-27.1 \\
-18.4 \\
-12.7 \\
-13.3 \\
-1.4 \\
-31.9 \\
-30.5\end{array}$ \\
\hline $\begin{array}{l}144-878 \mathrm{~A}- \\
44 \mathrm{M}-1,11-14 \\
44 \mathrm{M}-1,27-28 \\
44 \mathrm{M}-1.47-49 \\
44 \mathrm{M}-1,70-73 \\
44 \mathrm{M}-1.79-81 \\
44 \mathrm{M}-1.126-128\end{array}$ & $\begin{array}{l}406.21 \\
406.37 \\
406.57 \\
406.80 \\
406.89 \\
407.36\end{array}$ & $\begin{array}{l}\text { Volcanic breccia } \\
\text { Volcanic breccia } \\
\text { Volcanic breccia } \\
\text { Volcanic breccia } \\
\text { Volcanic breccia } \\
\text { Volcanic breccia }\end{array}$ & $\begin{array}{l}0.04 \\
0.00 \\
0.06 \\
\text { ND } \\
\text { ND } \\
0.04\end{array}$ & $\begin{array}{l}4.23 \\
6.52 \\
2.43 \\
\mathrm{ND} \\
\mathrm{ND} \\
1.94\end{array}$ & $\begin{array}{l}\text { ND } \\
\text { ND } \\
\text { ND } \\
\text { ND } \\
\text { ND } \\
\text { ND }\end{array}$ & $\begin{array}{l}\text { ND } \\
\text { ND } \\
\text { ND } \\
\text { ND } \\
\text { ND } \\
\text { ND }\end{array}$ & $\begin{array}{l}-43.5 \\
-46.1 \\
-45.3 \\
-42.7 \\
-44.5 \\
-41.7\end{array}$ \\
\hline $\begin{array}{l}144-879 \mathrm{~A}- \\
16 \mathrm{R}-1,113-115 \\
17 \mathrm{R}-1,74-76 \\
17 \mathrm{R}-2,24-25\end{array}$ & $\begin{array}{l}141.93 \\
151.16 \\
152.14\end{array}$ & $\begin{array}{l}\text { Wackestone } \\
\text { Clay, black } \\
\text { Clay, black }\end{array}$ & $\begin{array}{l}0.21 \\
1.90 \\
1.67\end{array}$ & $\begin{array}{l}0.83 \\
3.71 \\
0.65\end{array}$ & $\begin{array}{l}0.00 \\
0.00 \\
0.00\end{array}$ & $\begin{array}{l}0.00 \\
0.00 \\
0.00\end{array}$ & $\begin{array}{l}-34.1 \\
-22.8 \\
-32.3\end{array}$ \\
\hline
\end{tabular}

Notes: TOC = total organic carbon (from Table 3), $\mathrm{S}=$ total sulfur (from Table 3 ), $\mathrm{S}_{\text {org }}=$ organic sulfur, and $\delta^{34} \mathrm{~S}=$ sulfur isotope composition of pyrite (in \% deviation from the CDT standard). $\mathrm{ND}=$ no determination.

the sulfur enrichment. Hydrothermal alterations of basalts in the Marshall Island guyots have been identified by Holmes (this volume), but in all cases the altered intervals are overlain by remnants of thick pedogenic profiles formed by subaerial weathering under tropical or subtropical conditions. The pyritization of the ITP clearly postdates the pedogenic processes, and no indication of hydrothermal fluids penetrating the pedogenic rocks has been observed.

The question of hydrothermal influence can also be addressed from the sulfur isotope data. In hydrothermal processes, fractionation between sulfur species is small, and the sulfur isotope composition of hydrothermally precipitated sulfides will reflect the origin of the sulfur, in the present case either as magmatic or seawater sulfur (Ohmoto, 1972; Coleman, 1977). Sulfides in ocean floor basalts have $\delta^{34} \mathrm{~S}$ values close to zero (from $-2 \%$ to $+5 \%$, Sakai et al., 1978; Sakai et al., 1984; Puchelt and Hubberten, 1980). The isotope composition of dissolved, marine sulfate has varied between $+10 \%$ and $+35 \%$ depending on age (Claypool et al., 1980; Burdett et al., 1989). The observed sulfur isotope distribution (Fig. 5) is not compatible with any of these sources, but clearly points to microbial sulfate reduction. In Recent sediments, initial sulfate reduction is often accompanied by a sulfur isotope fractionation between seawater sulfate and produced $\mathrm{H}_{2} \mathrm{~S}$ of $50 \%$ or more, $\mathrm{H}_{2} \mathrm{~S}$ being the isotopically depleted species (e.g., Rees, 1973; Chambers and Trudinger, 1979; Goldhaber and Kaplan, 1980). Pyrite samples from the upper part of the ITP in the Marshall Islands guyots are characterized by fairly constant $\delta^{34} \mathrm{~S}_{\mathrm{py}}$ values of $-24 \%$ to $-32 \%$. The estimated ages of these deposits are Campanian to late Paleocene corresponding to seawater sulfate isotope ratios between $+16 \%$ and $+20 \%$ (Claypool et al., 1980). The 
Table 8. Iron analyses of selected samples from the ITP sequence.

\begin{tabular}{|c|c|c|c|c|c|c|c|c|c|}
\hline $\begin{array}{l}\text { Core, section, } \\
\text { interval }(\mathrm{cm})\end{array}$ & $\begin{array}{l}\text { Depth } \\
\text { (mbsf) }\end{array}$ & Lithology & $\begin{array}{l}\mathrm{Fe}-\mathrm{HCl} \\
(\mathrm{wt} \%)\end{array}$ & $\begin{array}{l}\text { Fe-tot } \\
\text { (wt } \%)\end{array}$ & $\underset{(w t \%)}{S}$ & $\begin{array}{l}\mathrm{S}_{\mathrm{org}} \\
(\mathrm{wt} \%)\end{array}$ & $\begin{array}{l}\mathrm{Py}-\mathrm{Fe} \\
\text { (wt\%) }\end{array}$ & $\begin{array}{c}\text { Excess Fe } \\
(w t \%)\end{array}$ & $\begin{array}{l}\text { DOP } \\
\text { Py-Fe }\end{array}$ \\
\hline \multicolumn{10}{|l|}{$144-871 \mathrm{C}-$} \\
\hline $32 \mathrm{R}-1,41-42$ & 422.91 & Clay, black & 0.45 & 19.55 & 12.6 & ND & 11.0 & 8.1 & 0.96 \\
\hline $32 \mathrm{R}-1,52-53$ & 423.02 & Clay, gray & 0.30 & 16.09 & 3.2 & ND & 2.8 & 13.0 & 0.90 \\
\hline \multicolumn{10}{|l|}{$144-874 B-$} \\
\hline $21 \mathrm{R}-1,0-5$ & 162.80 & Clay, black, pyritic & 2.55 & 18.83 & 16.2 & 0.0 & 14.1 & 2.2 & 0.85 \\
\hline $21 \mathrm{R}-1,25-27$ & 163.05 & Clay, black, pyritic & 1.14 & 5.22 & 13.5 & 0.0 & 11.7 & 2.4 & 0.91 \\
\hline $21 \mathrm{R}-1,35-36$ & 163.15 & Clay, black, pyritic & 2.08 & 16.29 & 17.9 & 0.0 & 15.6 & -1.4 & 0.88 \\
\hline $21 \mathrm{R}-1.74-75$ & 163.54 & Clay, gray, pyritic & 0.10 & 15.80 & 16.6 & ND & 14.4 & 1.3 & 0.99 \\
\hline $21 \mathrm{R}-1,93-94$ & 163.73 & Clay, gray, pyritic & 0.10 & 6.01 & 3.2 & ND & 2.8 & 3.1 & 0.97 \\
\hline $21 R-1,112-113$ & 163.92 & Clay, gray, pyritic & 4.48 & 10.30 & 3.1 & ND & 2.7 & 3.1 & 0.38 \\
\hline \multicolumn{10}{|l|}{ 144-877A- } \\
\hline $20 \mathrm{R}-1,81-82$ & 183.51 & Clay, black, peaty & 0.32 & 10.23 & 14.4 & ND & 12.5 & -2.6 & 0.98 \\
\hline 20R-1, 92-94 & 183.62 & Clay, black, peaty & 0.18 & 9.33 & 10.0 & 2.3 & 6.7 & 2.5 & 0.97 \\
\hline 20R-2, 1-2 & 183.76 & Clay, black, peaty & 2.43 & 20.45 & 25.2 & ND & 21.9 & -3.9 & 0.90 \\
\hline $20 \mathrm{R}-2,15-16$ & 183.95 & Clay, black, peaty & 1.22 & 16.94 & 18.0 & 4.7 & 11.6 & 4.1 & 0.90 \\
\hline $20 \mathrm{R}-2,34-35$ & 184.14 & Clay, black, peaty & 1.64 & 20.88 & 22.5 & n.d & 19.6 & -0.4 & 0.92 \\
\hline $20 \mathrm{R}-2,61-62$ & 184.36 & Clay, gray & 0.10 & 6.27 & 6.7 & ND & 5.9 & 0.3 & 0.98 \\
\hline $20 \mathrm{R}-2,126-127$ & 185.01 & Clay, gray & 0.39 & 20.03 & 23.0 & n.d & 20.1 & -0.4 & 0.98 \\
\hline $20 \mathrm{R}-3,9-10$ & 185.36 & Clay, gray & 0.96 & 19.21 & 13.7 & ND & 11.9 & 6.4 & 0.93 \\
\hline $20 \mathrm{R}-3,39-40$ & 185.66 & Clay, gray & 3.69 & 15.69 & 13.7 & ND & 11.9 & 0.1 & 0.76 \\
\hline
\end{tabular}

Notes: $\mathrm{Fe}-\mathrm{HCl}=$ iron extracted by hot $\mathrm{HCl}$. Fe-tot = total iron, extracted by aqua regia. $\mathrm{S}=$ total sulfur (from Table 3 ). $\mathrm{S}_{\mathrm{org}}=$ organic sulfur (from Table 7). Py-Fe = iron in pyrite calculated from sulfur data. Excess $\mathrm{Fe}=$ iron calculated as difference between total iron and pyrite iron. $\mathrm{DOP}=$ degree of pyritization calculated as ratio between pyrite iron and $\mathrm{HCl}$ extracted iron. $\mathrm{ND}=$ no determination.

pyrite/seawater isotopic fractionation $\left(\alpha^{34}\right.$ sulfate-py $)$ for the ITP is thus approximately $50 \%$, which is in accordance with the expected values for initial bacterial sulfate reduction. Pyrites from the top of the Albian polymictic breccia at Site 878 are consistently lighter in sulfur isotopes, $\delta^{34} \mathrm{~S}_{\mathrm{py}}$ varying from $-46.1 \%$ to $-41.7 \%$. Interestingly, this time interval is characterized by a negative anomaly in the seawater sulfate isotope curve reaching $\delta^{34} \mathrm{~S}_{\mathrm{py}}$ values as light as $+12 \%$ (Claypool et al., 1980), which could explain the lighter $\delta^{34} S_{p y}$ values. The only $\delta^{34} S_{p y}$ values consistent with a hydrothermal, magmatic origin are found deeper in the ITP sequence at Site 877A (Table 7). However, these values are part of a well-defined downward trend in sulfur isotope composition (Fig. 6) and reflect sulfate reduction in a progressively more closed system (e.g., Jørgensen, 1979; Raiswell, 1982).

In principle, pyrite formation is a two-step process. The first step involves reduction of dissolved sulfate to $\mathrm{H}_{2} \mathrm{~S}$ and oxidation of organic matter to $\mathrm{CO}_{2}$ or $\mathrm{HCO}_{3}$ by activity of anaerobic bacteria; the second step is precipitation of pyrite by reactions between $\mathrm{H}_{2} \mathrm{~S}$, elemental sulfur, and variable phases of intermediate iron monosulfides such as mackinawite and greigite (Berner, 1970; Goldhaber and Kaplan, 1974; Schoonen and Barnes, 1991). The first step is limited by availability of dissolved sulfate and metabolizable organic matter (Jørgensen, 1977; Berner, 1984), whereas the second step to a large degree is limited by the amount of reactive iron (Berner, 1969, 1984; Canfield, 1989). Sulfate reducers mainly rely on low-molecular-weight organic compounds for their metabolism and depend on microbial fermentation of highly reactive biopolymers like proteins and carbohydrates (LeGall and Postgate, 1973; Jørgensen, 1977). Oxidation of the organic matter by molecular oxygen is the major factor controlling the preservation of these biopolymers, and rapid burial of organic matter is therefore critical to the sulfate reducers.

In the ITP sequence, the amount of organic matter in the sediments may give a first hand indication of the locus of sulfate reduction. The black clay of Lithofacies B is the only unit characteristically enriched in TOC. The organic matter, however, is highly refractory. This may either reflect a dominant terrestrial source, or what is more plausible in this case, strong bacterial degradation of an originally mixed source of terrestrial and marine organic matter. Both the carbon isotope composition of the organic matter, the intermediate N/C ratios (atomic N/C close to 0.01 , Fig. 3) and the mixed GC traces seen for the SOM indicate a significant contribution of marine, algal organic matter.

In marine sediments, amounts of organic matter and pyrite sulfur will be roughly correlated (Berner and Raiswell, 1983; Berner, 1984). As seen from Figure $3 \mathrm{~A}$, this is not the case for the ITP sequence.
Here, the S content is high and independent of TOC. Berner and Raiswell (1983) excluded migrated sulfur from their data base. In the ITP sequence, migrated sulfur makes a considerable contribution to the total amount of pyrite sulfur, and direct conclusions regarding the depositional environments cannot be drawn from the data. Even when all obvious migrated sulfur data are excluded (see Fig. 3A), the distribution does not resemble euxinic or semi-euxinic conditions as described by Berner (1984) or Raiswell and Berner (1985), but rather indicates unlimited access of organic matter and sulfate to a sulfatereducing system, where iron is the limiting factor for pyrite precipitation (Calvert and Karlin, 1991).

The high DOP values (Table 8) support the concept of iron limitation to pyrite formation. In the organic-rich black clays of Lithofacies B, iron content is high (from $10 \%$ to $20 \%$ ), reflecting the lateritic origin of the clay. Nevertheless, virtually all iron has been converted to pyrite. The sulfur isotope composition of this pyrite $(-30 \%$ to $-20 \%$ ) shows how its formation took place during the phase of initial sulfate reduction, where access to dissolved seawater sulfate did not limit the rate of sulfate transformation. Simple stoichiometry (Berner, 1984) suggests that oxidation of four organic carbon atoms is needed to form one pyrite molecule. Thus, organic matter in the range of at least 0.3 to $0.8 \mathrm{~g} \mathrm{TOC} / \mathrm{cm}^{3}$ must have reacted to account for the amount of pyrite observed in the black clay. This is comparable to the amount of residual organic carbon in the clay today.

The strong sulfur enrichment in the organic-poor clays of Lithofacies $\mathrm{C}$ and $\mathrm{D}$ reflects downward diffusion of $\mathrm{H}_{2} \mathrm{~S}$ from the sulfatereducing intervals in the black clays above. In normal marine systems, only a minor fraction of the $\mathrm{H}_{2} \mathrm{~S}$ produced by the sulfate reducers is mineralized as iron sulfides (Jørgensen, 1977). Most of the $\mathrm{H}_{2} \mathrm{~S}$ diffuses to the surface, where it is oxidized to elemental sulfur or sulfate. Sulfide profiles from modern sediments do, however, indicate that small amounts of $\mathrm{H}_{2} \mathrm{~S}$ occur in the pore water below the zone of most intense sulfate reduction and iron sulfide precipitation (e.g., Berner, 1969; Jørgensen, 1977; Calvert and Karlin, 1991). In marine environments, where iron is the limiting factor for iron sulfide precipitation, reactive iron may thus be totally depleted below the uppermost few centimeters of bottom sediments. If the sulfate reducing horizon is transgressive over nonmarine deposits, however, sulfidization of reactive iron will proceed downward, and diffusion-determined profiles of iron sulfides will develop (Berner, 1969). Striking examples of this have been described from the Baltic Sea (Boesen and Postma, 1988) and Kau Bay in Indonesia (Middelburg, 1991). In both cases, organicrich, anoxic sediments of marine origin overlie fresh water deposits of 


\section{Initial Transgressive Phase: Complete Facies Association}

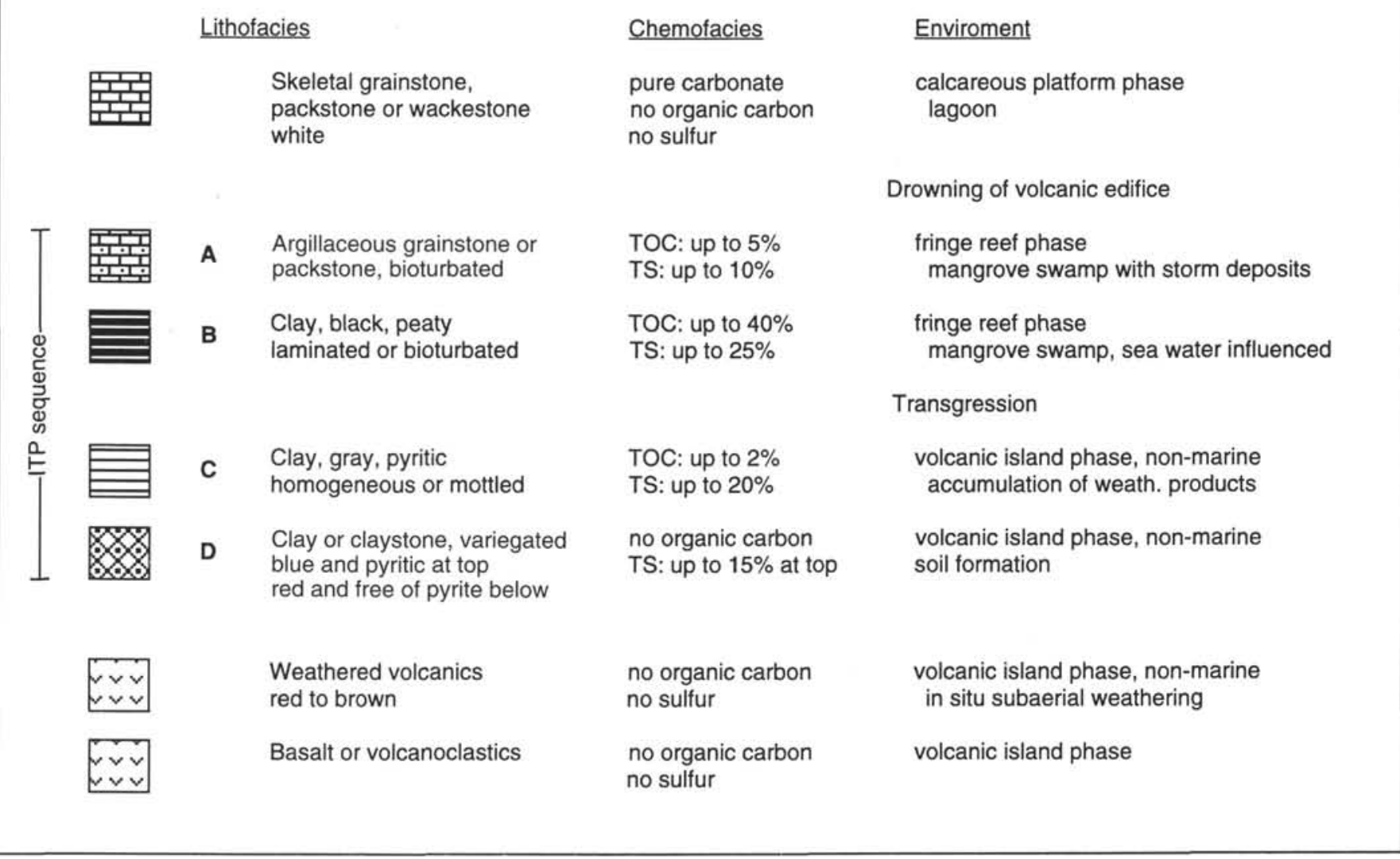

Figure 7. Comparison of lithofacies and chemofacies for the ITP sequence in the western Pacific guyots and their interpretation as depositional environments.

late Weichselian age. In the Baltic, the pyritization front has migrated approximately $0.5 \mathrm{~m}$ downward over a period of $7700 \mathrm{yr}$.

A scenario comparable to the Baltic Sea and Kau Inlet examples is likely for the pyrite-containing clay and claystone below the organic-rich clay in the ITP sequence. Here, relative sea level rises led to transgression of terrestrial deposits formed by intense subaerial weathering of the volcanic surface. The clays were enriched in iron, and virtually all iron-containing minerals in the basalts were oxidized to goethite and hematite (Holmes, this volume). Reactions between dissolved pore-water sulfide and goethite and hematite are rapid (total reaction within 100 yr or less: Canfield, 1989; Pyzik and Sommer, 1981; Canfield et al., 1992), and easily keep pace with the downward $\mathrm{H}_{2} \mathrm{~S}$ diffusion. A direct result of this process is the reduction of red colored iron pigment (mainly hematite) to blue-green or gray ferrous compounds, creating the conspicuous reduction front as seen at Sites 871,874 , and 877.

Sulfur isotope composition of pyrites in the gray clay and claystone of Lithofacies C and D vary between $-40 \%$ and $-1 \%$ in accordance with their microbial origin. An example of the interrelationship between $\delta^{34} \mathrm{~S}, \mathrm{~S}, \mathrm{DOP}$, and TOC for Hole $877 \mathrm{~A}$ is shown in Figure 6. This hole represents the complete development of the ITP sequence. Most intense sulfidization took place immediately below the most organic carbon-enriched upper part of the black clay unit (high $\mathrm{S}$ and DOP). Here, the iron content was higher than in the "TOC-diluted," peaty black clay. The downward enrichment in the heavy sulfur isotope seen in the gray clay must reflect sulfate reduction in a progressively more closed system. A second S enrichment deeper in the profile between 185 and 186 mbsf could indicate truncation of an earlier sulfate reduction profile before deposition of the gray clay. The return of the $\delta^{34} \mathrm{~S}$ values to a more open system signature at this level is in accordance with this interpretation.

Iron disulfide mineralogy and crystallinity is mainly controlled by pore-water $\mathrm{pH}$ (Schoonen and Barnes, 1991). At pH above 6, anhedral aggregates of pyrite $<5 \mu \mathrm{m}$ were the only iron disulfide phase, whereas larger, euhedral aggregates of both pyrite and marcasite formed at lower $\mathrm{pH}$. Marcasite was the only precipitate at $\mathrm{pH}$ below 4. In the ITP sequence, the organic-rich clay of Lithofacies B contained anhedral pyrite, which mainly occurred as $\mu \mathrm{m}$-thin coatings and encrustations on organic particles (PI. 1). Here, the intense sulfate reduction led to increased alkalinity, and $\mathrm{pH}$ was well above 6 . In contrast, the organic-free clay and claystone of Lithofacies C and D contained euhedral, millimeter-sized aggregates of both pyrite and marcasite (Pl. 1). This suggests a pore-water $\mathrm{pH}$ between 4 and 6 . Further down in the profiles, below the reduction front, the identification of natroalunite and natrojarosite (Holmes, this volume) indicates reactions between clay minerals and sulfuric acid at $\mathrm{pH}$ probably below 3 . The sulfuric acid probably formed by oxidation of $\mathrm{H}_{2} \mathrm{~S}$ diffusing from the zone of intense sulfate reduction above (Holmes and Buchardt, unpubl. data).

\section{SUMMARY AND CONCLUSIONS}

The west Pacific guyots drilled during the ODP Leg 144 all gave evidence in support of the classic Darwinian model for the evolution of atolls and lagoon islands: growth and drowning of a volcanic edifice and formation of a carbonate platform (Darwin, 1842). The high quality drilling provided unprecedented opportunities for detailed investigations of the nature of the initial transgressive phase 
(ITP) at the guyots. It was possible to establish a characteristic lithofacies association for the ITP, for which we choose the sequence in Hole $877 \mathrm{~A}$ at the Wodejebato Guyot as model. The lithofacies association included (from bottom to top): subaerially weathered basalts, clay and claystone with relict volcanic textures, mottled clay, black organic-rich mud, and argillaceous limestone (see Fig. 7). On top of the argillaceous limestone was white, pure carbonates characteristic of the carbonate platform phase of the guyots. The most conspicuous geochemical trait of the ITP was the strong sulfur enrichment seen in the black and mottled clays. Pyrite was the dominant sulfur mineral in these clays.

The present study has focused on the character and origin of the sulfur enrichment and its relation to the general depositional history of the guyots. We have reached the following conclusions:

1. Sulfur enrichment in the form of pyrite can be identified at the transition from subaerial to subaquatic environments in all drilled guyots.

2. The sulfur enrichment was caused by intense bacterial sulfate reduction in pools occasionally fed by sea water, either through high tides or major storms. Neither organic matter nor dissolved sulfate seems to be a limiting factor for sulfate reduction and sulfidization.

3. Excess $\mathrm{H}_{2} \mathrm{~S}$ formed by the sulfate reduction diffused downward and led to sulfidization and reduction of the underlying clays at depths up to $4 \mathrm{~m}$. Below the reduction front, sulfuric acid formed by oxidation of $\mathrm{H}_{2} \mathrm{~S}$ reacted with clay minerals to form small amounts of natroalunite and natrojarosite.

4. Iron was the limiting factor for pyrite precipitation in the ITP deposits. However, as the iron concentration was high in the detrital components of the ITP (they formed as lateritic soils), large amounts of pyrite could precipitate (up to $50 \%$ by weight of the rocks in some cases).

5. Pyrite grew as anhedral encrustations on organic particles in the $\mathrm{HCO}_{3}-$ buffered, high-pH pore water of the black mud and as euhedral aggregates in the clays below.

6. The depositional environment for the ITP evolved from subaerial conditions, characterized by deep weathering of the volcanic edifice under tropical climates (lateritization) to shallow water, marine, sheltered pools with high organic productivity and intense sulfate reduction. These pools gradually transformed into true lagoons dominated by calcareous deposits.

\section{ACKNOWLEDGMENTS}

The numerous analyses reported in this paper have been obtained by the tedious and careful work of many people, of whom special thanks shall go to Birgit Damgaard, Dennis K. Graham, Inge Juul, Anne Pimmel, Birte Warming, and Casper Westergaard. This paper benefited from discussions with Carsten Israelson and Jesper K. Nielsen. Reviews by R.L. Patience and R. Raiswell are greatly appreciated. The participation of BB in ODP Leg 144 was made possible by a grant from the Danish Science Foundation.

\section{REFERENCES $*$}

Andersen, H.C., 1903. Eventyrog Historier: København (Gyldendal), 344-358. Berner, R.A., 1969. Migration of iron and sulfur within anerobic sediments during early diagenesis. Am. J. Sci., 267:19-42.

, 1970. Sedimentary pyrite formation. Am. J. Sci., 268:1-23.

1984. Sedimentary pyrite formation: an update. Geochim. Cosmochim. Acta, 48:605-615.

Berner, R.A., and Raiswell, R., 1983. Burial of organic carbon and pyrite sulfur in sediments over Phanerozoic time: a new theory. Geochim. Cosmochim. Acta, 47:855-862.

\footnotetext{
-Abbreviations for names of organizations and publications in ODP reference lists follow the style given in Chemical Abstracts Service Source Index (published by American Chemical Society).
}

Boesen, C., and Postma, D., 1988. Pyrite formation in anoxic environments in the Baltic. Am. J. Sci., 288:575-603.

Buchardt, B., Clausen, J., and Thomsen, E., 1986. Carbon isotope composition of Lower Palaeozoic kerogen: effects of maturation. Org. Geochem., 10:127-134.

Buchardt, B., and Nielsen, M.V., 1991. Comparison of organic geochemical and palynofacies methods: example from the Gassum Formation (Late Triassic) in Denmark. Bull. Geol. Soc. Den., 38:267-277.

Burdett, J.W., Arthur, M.A., and Richardson, M., 1989. A Neogene seawater sulfur isotope age curve from calcareous pelagic microfossils. Earth Planet. Sci. Lett., 94:189-198.

Calvert, S.E, and Karlin, R.E., 1991. Relationships between sulphur, organic carbon, and iron in modern sediments of the Black Sea. Geochim. Cosmochim. Acta, 55:2483-2490.

Canfield, D.E., 1989. Reactive iron in marine sediments. Geochim. Cosmochim. Acta, 53:619-632.

Canfield, D.E., Raiswell, R., and Bottrell, S. 1992. The reactivity of sedimentary iron minerals toward sulfide. Am. J. Sci., 292:659-683.

Canfield, D.E., Raiswell, R., Westrich, J.T., Reaves, C.M., and Berner, R.A., 1986. The use of chromium reduction in the analysis of reduced inorganic sulfur in sediments and shale. Chem. Geol., 54:149-155.

Chambers, L.A., and Trudinger, P.A., 1979. Microbiological fractionation of stable sulfur isotopes: a review and critique. Geomicrobiol. J., 1:249-293.

Chitale, D.V., and Güven, N., 1987. Natroalunite in a laterite profile over Deccan Trap basalts at Matanumad, Kutch, India. Clays Clay Miner., $35: 196-202$.

Claypool, G.E., Holser, W.T., Kaplan, I.R., Sakai, H., and Zak, I., 1980. The age curves of sulfur and oxygen isotopes in marine sulfate and their mutual interpretation. Chem. Geol., 28:199-260.

Craig, H., 1957. Isotopic standards for carbon and oxygen and correction factors for mass-spectrometric analysis of carbon dioxide. Geochim. Cosmochim. Acta, 12:133-149.

Coleman, M.L., 1977. Sulphur isotopes in petrology. J. Geol. Soc. London, 133:593-608.

Darwin, C., 1842. The Structure and Distribution of Coral Reefs (Part I of The Geology of the Voyage of the Beagle): London (Smith, Elder).

Dean, W.E., Arthur, M.A., and Claypool, G.E., 1986. Depletion of $\delta^{13} \mathrm{C}$ in Cretaceous marine organic matter: source, diagenetic, or environmental signal? Mar. Geol., 70:119-157.

Deines, P., 1980. The isotopic composition of reduced organic carbon. In Fritz, P., and Fontes, J.C. (Eds.), Handbook of Environmental Isotope Geochemistry (Vol. 1): The Terrestrial Environment, A: Amsterdam (Elsevier), 329-406.

Emery, K.O., Tracey, J.I., Jr., and Ladd, H.S., 1954. Geology of Bikini and Nearby Atolls. Geol. Surv. Prof. Pap. U.S., 260-A.

Espitalié, J., Laporte, J.L., Leplat, P., Madec, M., Marquis, F., Paulet, J., and Boutefeu, A., 1977. Méthode rapide de caractérisation des roches mères, de leur potentiel pétrolier et de leur degré d'évolution. Rev. Inst. Fr. Pet., 32:23-42.

Goldhaber, M.B., and Kaplan, I.R., 1974. The sulfur cycle. In Goldberg, E.D. (Ed.), The Sea (Vol. 5): New York (Wiley-Interscience), 569-655.

, 1980. Mechanisms of sulfur incorporation and isotope fractionation during early diagenesis in sediments of the Gulf of California. Mar. Chem., 9:95-143.

Hein, J.M., Richmond, B.M., Gray, S.C., Hausmann, R., Colgan, M.W., El Sabbagh, D., and Gein, L.M., 1988. Description, mineralogical, chemical, and isotopic compositions, petrography, diagenesis, and uranium series ages of drill cores from the lagoon of Aitutaki, Cook Islands. Open-File Rep.-U.S. Geol. Surv., 88-419.

Hoefs, J., 1987. Stable Isotope Geochemistry (3rd ed.): Berlin (Springer).

Jørgensen, B.B., 1977. The sulfur cycle of a coastal marine sediment (Limfjorden, Denmark). Limnol. Oceanogr., 22:814-832.

, 1979. A theoretical model of the stable sulfur isotope distribution in marine sediments. Geochim. Cosmochim. Acta, 43:363-374.

LeGall, J., and Postgate, J.R., 1973. The physiology of sulphate-reducing bacteria. Adv. Microbial Physiol., 10:81-133.

Lewan, M.D., 1986. Stable carbon isotopes of amorphous kerogens from Phanerozoic sedimentary rocks. Geochim. Cosmochim. Acta, 50:15831591.

Middelburg, J.J., 1991. Organic carbon, sulphur, and iron in Recent semieuxinic sediments of Kau Bay, Indonesia. Geochim. Cosmochim. Acta, $55: 815-828$.

Ohmoto, H., 1972. Systematics of sulfur and carbon isotopes in hydrothermal ore deposits. Econ. Geol., 67:551-579. 
Premoli Silva, I., Haggerty, J., Rack, F., et al., 1993. Proc. ODP, Init. Repts., 144: College Station, TX (Ocean Drilling Program).

Puchelt, H., and Hubberten, H.W., 1980. Preliminary results of sulfur isotope investigations on deep sea drilling project cores from Legs 52 and 53. In Donnelly, T., Francheteau, T., Bryan, W., Robinson, P., Flower, M., Salisbury, M., et al., Init. Repts. DSDP, 51, 52, 53 (Pt. 2): Washington (U.S. Govt. Printing Office), 1145-1148.

Pyzik, A.J., and Sommer, S.E., 1981. Sedimentary iron monosulfides: kinetics and mechanism of formation. Geochim. Cosmochim. Acta, 45:687-698.

Raiswell, R., 1982. Pyrite texture, isotopic composition and the availability of iron. Am. J. Sci., 282:1244-1263.

Raiswell, R., and Berner, R.A., 1985. Pyrite formation in euxinic and semieuxinic sediments. Am. J. Sci., 285:710-724.

Rees, C.E., 1973. A steady state model for sulfur isotope fractionation in bacterial reduction processes. Geochim. Cosmochim. Acta, 37:1141-1162.

Sager, W.W., Winterer, E.L., Firth, J.V., et al., 1993. Proc. ODP, Init. Repts., 143: College Station, TX (Ocean Drilling Program).
Sakai, H., Des Marais, D.J., Ueda, A., and Moore, J.G., 1984. Concentrations and isotope ratios of carbon, nitrogen and sulfur in ocean-floor basalts. Geochim. Cosmochim. Acta, 48:2433-2441.

Sakai, H., Ueda, A., and Field, C.W., 1978. $8^{34}$ S and concentration of sulfide and sulfate sulfurs in some ocean-floor basalts and serpentinites. Fourth Int. Conf. Geochronology, Cosmochronology and Isotope Geology. OpenFile Rep.-U.S. Geol. Surv., 78-701:372-374.

Schlanger, S.O., 1963. Subsurface geology of Eniwetak Atoll. Geol. Surv. Prof. Pap. U.S., 260-BB:991-1066.

Schoonen, M.A.A., and Barnes, H.L., 1991. Reactions forming pyrite and marcasite from solution, II. Via FeS precursors below $100^{\circ} \mathrm{C}$. Geochim. Cosmochim. Acta, 55:1505-1514.

Date of initial receipt: 5 August 1994

Date of acceptance: 13 January 1995

Ms 144SR-060 

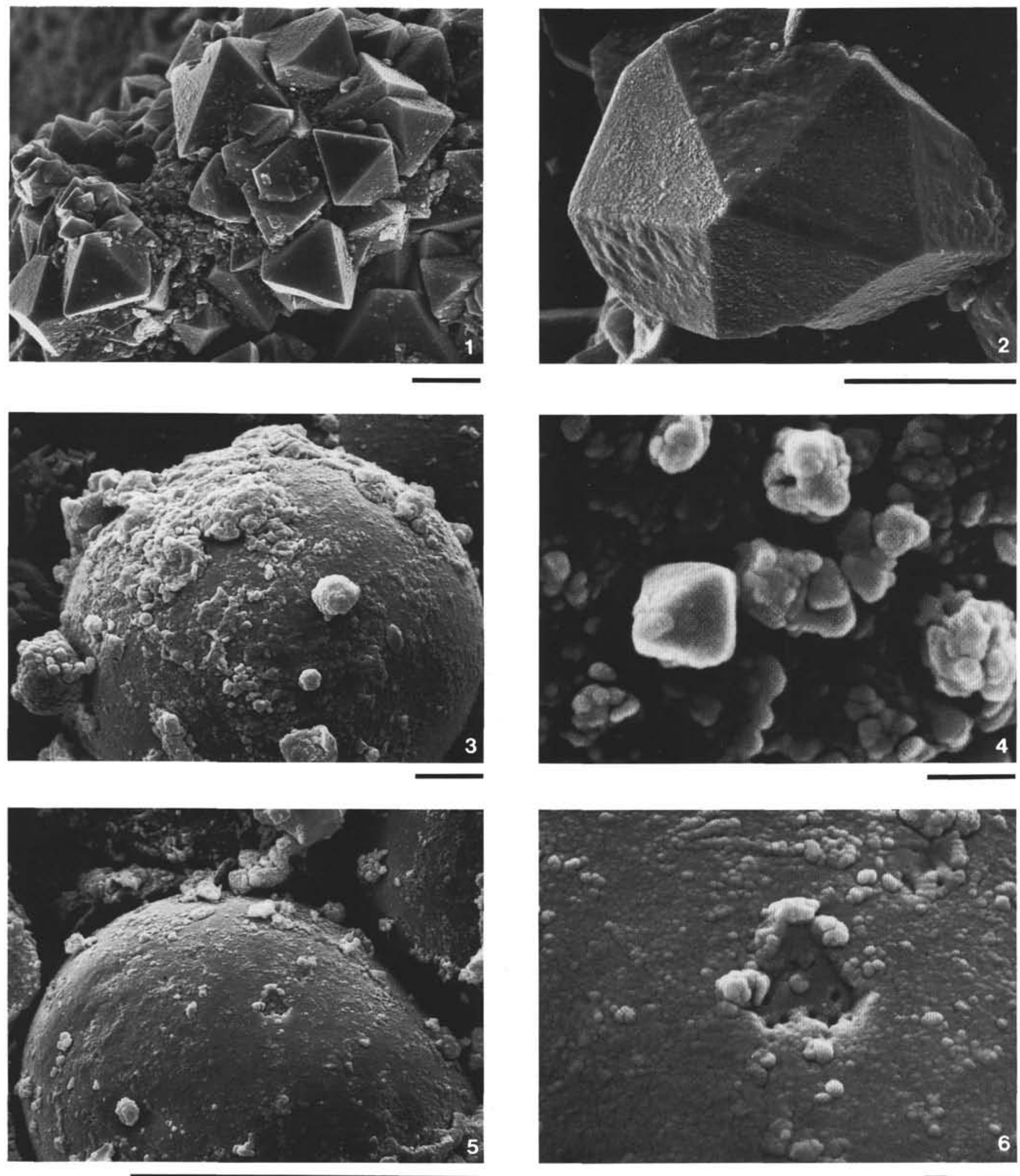

Plate 1. SEM micrographs of pyrite from the ITP sequence at Leg 144 Guyots. 1. Aggregate of euhedral pyrite crystals from the gray clay of Lithofacies C in Hole 877A. Scale is $10 \mu \mathrm{m}$. 2. Close-up of euhedral pyrite crystal from the same clay units as Figure 1. Scale is $10 \mu \mathrm{m}$. 3. Biogenic sphere (spore) with anhedral pyritic surface encrustation from black clay of Lithofacies B in Hole 877A. Scale is $10 \mu \mathrm{m}$. 4. Close-up of Figure 3 showing small octahedral pyrite crystal at surface of sphere. Scale is $1 \mu \mathrm{m}$. 5. Biogenic sphere (spore) with anhedral pyritic surface encrustation from black clay of Lithofacies B in Hole 871C. Scale is $10 \mu \mathrm{m}$. 6. Close-up of Figure 5 showing "window" in pyritic surface encrustation. Note pores in spore wall visible in window. Scale is $10 \mu \mathrm{m}$. 